呼吸器感染症に対するセフトリアキソンと セフォタキシムの薬効比較試験

杏林大学医学部第 1 内科

小林 宏行* 高村 研二押谷 博 二瓶 倫子

北海道大学医学部第 2 内科およびその協力機関

斎藤 玲 富沢磨須美 中山一朗

石川 清文 阿部 守邦 黒田 義彦

熊野 博之 栗原 義夫 菊人 剛

福山周三郎

国立札幌病院呼吸器科およびその協力機関

長浜 文雄安田㥁也鈴木 明 平賀 洋明萩 光春 久世 彰彦 今 寛 鈴木 克男 黒田 練介 下村壽太郎

弘前大学医学部第 3 内科拈よびその協力機関 武部 和夫 村上 誠一 相楽 衛男 筒井理裕 前田 俊一 大平 誠一 増田 光男 盛 勇造 佐々木和雄 鈴木 密雄 中園 誠 高橋 清仁 中畑 久 小坂 志郎

岩手医科大学第 3 内科捛よびその協力機関

田村 昌士 伊藤 隆司 村上 剛久 板倉康太郎

$$
\text { 東北大学医学部第 } 1 \text { 内科 }
$$

瀧島任井田士朗

東北大学抗酸菌病研究所内科

今野 淳 大沼 菊夫 大泉耕太郎 佐々木昌子渡辺彰青沼 清一 佐々木玲子

いわき市立総合磐城共立病院呼吸器科

林泉

国立霞ヶ浦病院内科

勝正 孝

東京厚生年金病院内科

真下 啓明 山根 至二 山岡 澄夫

別刷請求先：（テ181）東京都三鷹市新川 6-20-2 杏林大学医学部第 1 内科 小林 宏行
東京慈恵会医科大学第 2 内科

斉藤篤嶋田甚五郎柴孝也 山路 武久 北條 敏夫 加地正伸 宮原正

順天堂大学医学部内科

池本 秀雄 渡辺一功

東京共済病院内科

中川 圭一 渡辺健太郎 小山 優

飯島 福生

東京都養育院付属病院内科

島田馨 稲松 孝思 浦山 京子 虎の門病院呼吸器科

谷本 普一 吉村 邦彦 中谷 龍王 蝶名林直彦中森 祥隆中田紘一郎 国立病院医療センター呼吸器科

可部順三郎石橋 弘義 佐野 靖之 川崎市立川病院内科

藤森一平 小林芳夫 尾仲章男 横浜逓信病院内科

深 谷一太

神奈川県立長浜病院呼吸器科

小田切繁樹 室橋 光宇 池田 大忠 鈴木 周雄 金子 保

名古屋市立大学医学部第 1 内科拈よびその協力機関 武内 俊彦山本 俊幸加藤 政仁 新潟大学医学部第 2 内科

和田 光一 荒川 正昭 信楽園病院内科

関根 理 薄田 芳丸 青木 信樹 水原郷病院内科

山作房之輔 鈴木 康稔

富山県立中央病院内科

大山馨

京都大学結核胸部疾患研究所第 1 内科 扣よびその協力機関

前川 暢夫 中西 通泰 鈴木雄二郎 李啓充 
関西医科大学付属洛西 =ュータウン病院内科 大久保 滉上田 良弘 関西医科大学第 1 内科

岡本 緩子 前原 敬悟 米津 精文 飯田夕

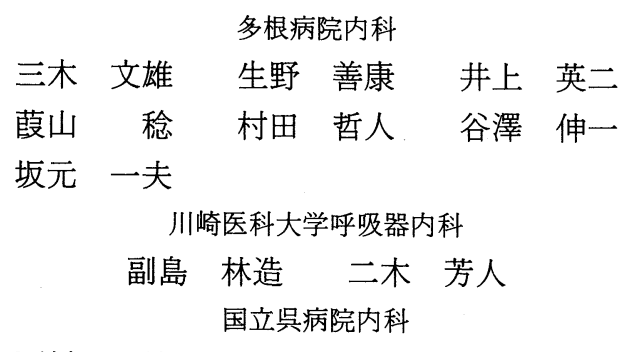

栗村 統 佐々木英夫 福原 弘文 徳島大学医学部第 3 内科

螺良 英郎 田村 正和 中川 勝
九州大学医療技術短期大学部，医学部第 1 内科

澤江 義郎 岡田 薫 熊谷 幸雄 国立療養所南福岡病院臨床研究部

長野準 久保 千春 大分医科大学第 2 内科

系賀 敬 那須 勝 後藤 純 後藤陽一郎 田代 隆良

長崎大学医学部第 2 内科拉よびその協力機関

原耕平 斎藤 厚山口 恵三

鈴山 洋司重野 芳輝 小江 俊行

岩崎 博圓林敏明

長崎大学熱帯医学研究所内科

松本 慶蔵野口 行雄田口 幹雄

\section{* 執筆者}

（昭和60年 7 月 11 日受付）

（昭和 60 年 10 月 8 日受理）

Key words : Respiratory tract infections, comparative study, ceftriaxone, cefotaxime

\section{要 旨}

セフェム系抗生物質セフトリアキソン (CTRX) の呼吸器感染症に対する有効性, 安全性拈よび有用 性を評価する目的でセフォタキシム（CTX）を対照薬として比較試験（well controlled comparative study）を実施した。

対象疾患は慢性気管支炎, びまん性沉細気管支炎の感染増悪および下気道感染を伴った慢性呼吸器疾 患（気管支拡張症，気管支喘息，肺気腫，肺線維症，陳旧性肺結核，肺癌など）ならびに細菌性肺炎と した. CTRX, CTX ともに 1 回1gを 1 日 2 回, 点滴にて原則として 7〜14日間投与した。 臨床効果, 細菌学的効果, 安全性, 有用性を検討し, 以下の成績を得た。

1）臨床効果：CTRX 群では，124例中著効 4 例，有効 96 例，やや有効 13 例, 無効 11 例, 有効率 $81 \%$, CTX 群では127例中著効 3 例，有効91例，やや有効12例，無効21例，有効率74\%であり，両群間に有意 差はみられなかった。

また, 重症度で層別すると中等症例では CTRX 群では67例中有効以上 54 例, 有効率 $81 \%$, CTX 群で は60例中有効以上 37 例，有効率 $62 \%$ であり，CTRX 群で有意にすぐれた成績が得られた。

なお，P. aeruginosa 感染例を除いてもCTRX 群で有意にすぐれた成績であった。

2) 細菌学的効果：CTRX 群では 44 例中消失 35 例, 消失率 $80 \%$, CTX 群では 54 例中消失 42 例, 消失率 78\%であり，両群間に有意差はみられなかった。菌別あるいは単独・混合感染別に層別しても両群間に 有意差はみられなかった。

3）副作用：副作用発現率は CTRX 群133例中 14 例，10.5\%, CTX 群143例中 9 例，6.3\%であり両群 間に有意差はみられなかった。副作用の症状別では CTRX 群で発診が有意に高い発現率であった.

臨床検查值異常は CTRX 群130例中37例，28.5\%, CTX 群137例中 36 例，26.3\%であり，両群間に有 
意差はみられなかった。

4）有用性：CTRX 群では133例中，極めて有用 3 例，有用 94 例，やや有用 13 例，有用性なし20例，判 定不能 3 例，CTX 群では143例中極めて有用 2 例，有用 90 例，やや有用14例，有用性なし28例，判定不 能 9 例であり, 両群間に有意差はみられなかった。

5）以上の成績より, CTRX は下気道領域の呼吸器感染症, すなわち, いわゆる慢性気道感染と肺炎に 対して臨床的に有用性が高い薬剤であると考㝋られた。

\section{緒 言}

セフトリアキソン (CTRX) はロシュ社で新ら しく開発されたセフェム系抗生物質であり，その 化学構造上の特徴は 7 位側鎖にメトキシイミノ基 抏よびアミノチアゾール基を，また 3 位側鎖にト リアジン基を有していることにある。

本剂については，すでに多くの基礎的研究をは じめ, 臨床的研究が行なわれて和り，わが国に拉 ける成績については第29回日本化学療法学会東日 本支部総会（仙台，1982年）の新薬シンポジゥム において発表されている1).

それによると, CTRX の抗菌スペクトラムは広 域であり, 各種細菌に対し殺菌的に作用し強い抗 菌力を呈するとされている。とくにグラム陰性菌 に対する抗菌力が強く, E. coli, K. pueumoniae H. influenzae 拈よび Proteus 属には $0.1 \mu \mathrm{g} / \mathrm{ml}$ 以 下の $\mathrm{MIC}_{50}$ 值が呈されている。反面，P. aeruginosa, S. faecalis に対しては $\mathrm{MIC}_{50}$ 值は $25 \mu \mathrm{g} / \mathrm{ml}$, $\mathrm{MIC}_{90}$ 值は $100 \mu \mathrm{g} / \mathrm{ml}$ と抗菌力が弱かった.

これら抗菌力はいわゆる第 3 世代のセフェム系 とほぼ同じ傾向といえるが，本剤の特徵はむしろ 血中濃度半減期が非常に長く1223) ヒトに静注した 場合 7 ～時間であるという点にあるといえよ う。また本剤は体内で汪とんど代謝されることな く，未変化体のま〉投与後 48 時間までにその 50 ６0\%が尿中へ排泄されている.

また，一般臨床試験に扮いて CTRX は呼吸器 感染症387例に対して76\%の有効率が得られてお り,一方副作用の発現は本剤が使用された 1,154 例 中 43 例 $3.7 \%$ と集計されている.このうち多くは下 痢, 発疹等であり重篤な例はみられていない1).

以上の基礎的ならびに臨床的成績を背景に著者 らは細菌性肺炎および慢性気管支炎等をはじめと するいわゆる下気道領域に拈ける呼吸器感染症に
対する CTRX の臨床効果, 安全性, 有用性等を評 価する目的で, セフォタキシム (以下 CTX) を対 照薬として比較試験 (well controlled comparative study）を行った.

\section{I. 試験方法}

1. 対象疾患ならびに対象症例

慢性気管支炎おょびびるん性沉細気管支炎の感 染性増悪, 下気道感染を伴った慢性呼吸器疾患 (気 管支拡張症, 気管支喘息, 肺気腫, 肺線維症, 陳 旧性肺結核，肺癌など）ならびに細菌性肺炎を対 象疾患とした。ただしマイコプラズマ肺炎あるい は原発性異型肺炎などの混入はやむを得ないもの とした．対象症例は入院患者を原則とし年齢は 16 歳以上，な拉対象とする症例にあらかじめ同意を 得ることとした。

また下記のような症例は対象から除外すること とした。

1）初診時重症で予後不良と思われるもの

2）本治療開始前の薬剤投与により,すでに症状 が改善しつつあるもの

3） P. aeruginosa S. faecalis が起炎菌と判断さ れるもの

4）セフェム, ペニシリンにアレルギー既往のあ るもの, 拉よびCTRX あるいは CTX 両薬剤に対 して皮内反応でいずれか一剤についてでも陽性と 判定されたもの

5）妊婦扰よび妊娠している可能性のある女性, 授乳中の女性

6）腎，肝機能に重篤な障害のあるもの

7）フロセマイドなどの利尿剂の併用を必要と するもの

8）との他，主治医が不適当と判断した例

2. 検討薬剤および投与方法

投与薬剤ならびに 1 日投与量は下記の 2 群であ 
り，各バイアル瓶を白色不透明のビニールフィル ムで被包し, 外観上識別不能とし, いずれも 1 症 例分 28 バイアルと保存用 2 バイアルの計 30 バイア ルを 1 箱に収め厳封した。

試験薬剤：CTRX $1 \mathrm{~g}$ (力価)/バイアル

対照薬剂：CTX $1 \mathrm{~g}$ (力価)/バイアル

上記 2 薬剂はそれぞれの 30 バイアル箱を単位と 乙無作為に割付け，一連コード番号が付された。 コントローラーには東京大学保健管理学教室, 田 中恒男教授があたり, 両薬剤の外観上の識別不能 性, 投与順序の無作為割付け, key code の保管な らびに開封，調査表に付されている薬剤番号およ び主治医による効果判定部分の切り取りとその保 管, 開封後のデータの不変性の保証ならびに解析 などを担当した。

な拈，両薬剂の 1 バイアル中の含量は，任意に 抽出したものにつき国立予防衛生研究所で試験を 行ない，それぞれ規格を満足することを確認する とともに，投薬終了後にもいずれも規格範囲内で あることが確認された（Table 1).

3. 投与方法揖よび期間

両薬剤とも 1 回 1 バイアルを 1 日 2 回, 原則と して10〜14時間ごとに $100 \sim 300 \mathrm{ml}$ の糖液または 電解質液で溶解し, 約 1 時間で点滴静注すること とし，また投与期間も原則として $7 〜 14$ 日間とし た.

な拈，投与薬剤を無効と判定して他剤へ変更す る場合は, 少なくとも本治療開始後72時間（6 ト イアル投与）後とした。また副作用のため投与継 続が不可能な場合や，前記対象疾患から除外すべ き患者の条件が投与開始後判明した場合，完全に 治癒した場合など主治医が中止の必要を認めた場 合には主治医の判断で投与中止することとした。

な颃この場合も投与中止時に所定の検查を可能な 限り実施し，中止の理由，中止時の所見などを調 査表に記入することとした。

4. 併用薬剤

1) 併用禁止薬剤

他の抗菌剤(ただし, streptomycin, kanamycin, rifampicin, envio mycin, lividomycin, capreomycin および viomycin 以外の抗結核剤はこの限りでは
Table 1 Stability of CTRX and CTX

\begin{tabular}{ccc}
\hline Drug & $\begin{array}{c}\text { Initial } \\
(\%)\end{array}$ & $\begin{array}{c}\text { Later } \\
(\%)\end{array}$ \\
\hline CTRX & 111.7 & 105.0 \\
CTX & 103.8 & 103.9 \\
\hline
\end{tabular}

ない.)

副腎皮質ステロイド（ただし本治療開始10日以 上前からステロイドが投与されて打り，それによ る症状の変化が認められず, かつ治療終了時まで 同量あるいはそれ以下の量が継続投与されている か，あるいは中止されている場合は差支えないも のとする).

\section{2）併用を認める薬剂}

袪痰剂，鎮咳剂，気道拡張剂，消炎効果を有さ ない喀痰融解剂々の他基礎疾患に対する一般治療 剂は併用を認めることとした。その他, 非ステロ イド系消炎剤, 消炎酵素剂, 解熱剂は原則として 併用を禁止するが止むをえず使用された場合はこ れを認めることとした，以上の併用剤，ならびに 基礎疾患, 合併症などに対して治療を施行した場 合は必ず調査表に併用理由と期間を記載すること とした。

5. 症状・所見の観察および臨床検査

1）臨床症状，所見の観察

体温, 喀嗽, 喀痰量および性状, 呼吸困難, 胸 痛, 胸部理学的所見, 脱水症状, チアノーゼ执よ び副作用等については原則として毎日観察するこ ととした。すた観察が所定の日に実施不可能な場 合は，前日または翌日に実施することにした。こ れら臨床症状, 所見の評価は以下の基準に従って 調査法に記入することとした。

体温：最高体温の実測值

咳嗽：睡眠が障害される程度 (H), なし $(-)$, その中間 $(+)$

喀疢量： $50 \mathrm{ml} /$ 日以上 (H), $50 \sim 10 \mathrm{ml} /$ 日 (H), $10 \mathrm{ml}$ 末満/日 $(+)$, なし (一)

喀痰性状：膿性 (P), 粘膿性 (PM), 粘性 (M) 呼吸困難：起座呼吸 (H), なし (一), その中 間 $(+)$

胸部ラ音：主治医の判断により (H), (+), ( - ) 
Fig. 1 Items and Schedule of Laboratory Test

\begin{tabular}{|c|c|c|c|c|}
\hline \multirow{2}{*}{ Items of laboratory test } & \multirow{2}{*}{$\begin{array}{c}\text { pre- } \\
\text { treatment }\end{array}$} & \multicolumn{3}{|c|}{$\begin{array}{l}\text { After initiation } \\
\text { of treatment }\end{array}$} \\
\hline & & on 3 day & on 7 day & on 14 day \\
\hline Chest X-ray & $\bigcirc$ & $x$ & $\bigcirc$ & $\bigcirc$ \\
\hline Arterial blood gas & $x$ & $x$ & $x$ & $\times$ \\
\hline Erythrocyte & $\bigcirc$ & & $\bigcirc$ & $\bigcirc$ \\
\hline Hemoglobin & $\bigcirc$ & & O & $\bigcirc$ \\
\hline Hematocrit & $\bigcirc$ & & O & O \\
\hline Thrombocyte & $\bigcirc$ & & O & $\bigcirc$ \\
\hline Leukocyte & $\bigcirc$ & $\bigcirc$ & O & $\bigcirc$ \\
\hline Leukogram & $\bigcirc$ & & O & $\bigcirc$ \\
\hline ESR (1hr. value) & $\bigcirc$ & & $\bigcirc$ & $\bigcirc$ \\
\hline $\mathrm{CRP}$ & $\bigcirc$ & $\bigcirc$ & O & $\bigcirc$ \\
\hline Cold hemagglutination & $\bigcirc$ & & & $\bigcirc$ \\
\hline Mycoplasma antibody (CF or IHA) & O & & & $\bigcirc$ \\
\hline Prothrombin time & $\bigcirc$ & & & O \\
\hline Direct Coombs test & $\times$ & & & $x$ \\
\hline S-GOT & O & & O & O \\
\hline S-GPT & $\bigcirc$ & & 0 & $\bigcirc$ \\
\hline Alkaline phosphatase & $\bigcirc$ & & $\bigcirc$ & $\bigcirc$ \\
\hline Total bilirubin & $x$ & & $\times$ & $x$ \\
\hline BUN & $\bigcirc$ & & $\bigcirc$ & $\bigcirc$ \\
\hline Serum creatinine & $\bigcirc$ & & $\bigcirc$ & $\bigcirc$ \\
\hline Urinary protein & $\bigcirc$ & & O & $\bigcirc$ \\
\hline Urinary sediment & $\bigcirc$ & & $\bigcirc$ & $\bigcirc$ \\
\hline Inspection of pathogen & $\bigcirc$ & $\times$ & $\bigcirc$ & O \\
\hline Blood culture & $\times$ & & & \\
\hline
\end{tabular}

$\bigcirc$ : indispensable $\times$ : should be performed as much as possible

胸痛, 脱水症状，チアノーゼ：あり $(+)$ ，なし (一)

副作用については，その症状，発現日，消失日， 投与継続の可否, 処置, 検討薬剤との関係などに ついて具体的に調査法に記録することとした。

\section{2）臨床検査}

胸部 線，末梢血一般検查所見，血液生化学的 所見，血清学的所見，尿所見扣よび起炎菌検索な どを経時的に観察することとした。各観察項目に 関する実施要綱は別記した（Fig. 1).

また, 喀痰を東京薬科大学第 2 微生物学教室 （河野恵教授）に送付し，菌の分離・同定扣よび CTRX, CTX に対する感受性を一括して測定し た.

6. 重症度および効果判定

1）主治医による判定

各主治医が独自の基準に従って, 重症度を重症,
中等症, 軽症の 3 段階に, また臨床効果を著効, 有効, やや有効, 無効の 4 段階㐨よび判定不能に, さらに有用性をあり，ややあり，なしの 3 段階に 判定した。

2）小委員会による判定

試験終了後, コントローラーにより薬剂番号, 施設名, 主治医名および主治医判定の記載された 部分を切り取った後，ランダム化された胸部レ線 フィルムをもとにして，小委員会で各症例毎に診 断名の確定, 解析対象としての適否, 重症度, 臨 床効果, 細菌学的効果, 副作用, 臨床検査值異常 ならびに有用性の判定を行った。

まず，本治療開始前の臨床症状，胸部レ線所見 および臨床検査值から診断名を確定し,肺炎群(細 菌性肺炎, 原発性異型肺炎など） と慢性気道感染 群（慢性気管支炎, びまん性沉細気管支炎の感染 増悪および下気道感染を伴った慢性呼吸器疾患) 
Table 2 Criteria for assessment of usefulness

\begin{tabular}{cccccc}
\hline $\begin{array}{c}\text { Side effects } \\
\text { and laboratory abnormalities }\end{array}$ & Excellent & Good & Fair & Poor & $\begin{array}{c}\text { Assessment } \\
\text { impossible }\end{array}$ \\
\hline None & + & + & \pm & - & $?$ \\
Mild & + & + & \pm & - & - \\
Moderate & + & \pm & - & - & - \\
Severe & \pm & - & - & - & - \\
\hline
\end{tabular}

H: Very useful, $+:$ Useful, $\pm:$ Slightly useful, - : Useless, ?: Assessment impossible

に大別した。つぎに試験実施要綱に照らしながら 各評価項目ごとに解析対象としての適否が検討さ れた。

肺炎群に抢ける胸部レ線フィルムについては, 1 枚ごとに病変の拡がり, 陰影の性状などから所 見の重症度を 0 点（正常） 10点（最重症）まで 11段階に分けて採点した。全フィルムの採点終了 後これを各症例ごとに整理し, 読影の客観性, 普 遍性を期しつつ，経過観察を行った。

感染症としての重症度は投与開始前の臨床症 状,胸部レ線所見㐨よび臨床検査值などから重症, 中等症, 軽症の 3 段階に判定した.

臨床効果は臨床症状括よび諸検査項目の推移か ら, 著効, 有効, やや有効, 無効の 4 段階扝よび 判定不能に判定した。

細菌学的効果は起炎菌を確定した後, その起炎 菌の消長を追跡し得た症例について, 各菌株ごと に消失，減少，不変と判定し，また交代菌につい ては別述確定した。

副作用および臨床検査異常については採否を決 定した後, その重症度を判定した。この場合の重 症度はそれ自身が疾患の予後に影響するよらな場 合を重度, 投与中止あるいは何らかの処置を必要 とした場合を中等度, 何ら処置を必要とせず投与 継続が可能であった場合を軽度とした。

有用性は臨床効果と副作用, 臨床検査值異常な どの重症度との組合せにより判定した(Table 2).

3）臨床症状, 所見の改善度

臨木症状, 所見, 胸部レ線像および臨床検査值 について，投与開始前の状態と比較してその改善 度を検討した。

7. キーコードの開封
小委員会による判定が行われた後, 条参加施設 の代表者, 主治医拈よびコントローラーの立合い のもとで小委員会判定が確認された後, キーコー ドが開封された。

\section{8. 成績の解析処置}

解析はノンパラメトリック手法を用い, 背景因 子, 臨床効果, 細菌学的効果, 臨床症状所見の改 善度, 副作用, 有用性などについて両薬剂群間の 比較を行った。統計手法は Wilcoxon の順位和検 定 $(\mathrm{W}), \chi^{2}$ 検定 $\left(\chi^{2}\right)$ または Fisher の直接確率 法 (F) を用い，両側危険率 $5 \%$ 以下を有意差あり とし, 10\%以下を傾向差ありとして参考に供した。

\section{II. 成}

\section{1. 集積症例}

検討薬剂の投与が行われた症例は288例(CTRX 群139例， CTX 群149例) であった。これら288例 について小委員会に拈いて解析対象としての適否 が検討され，12例は臨床効果，安全性，有用性の いずれの解析対象からも除外された。その内訳は 重篤な基礎疾患 9 例, 併用薬違反 2 例, 他の原因 による死亡 1 例であった（Fig. 2).

残りの276例については, すべて安全性の解析対 象として採用されたが，このうち臨床効果の解析 対象から除外されたものは25例であった。この理 由は，対象外疾患 15 例，副作用により中止 4 例， 感染症状不明確 4 例, 投与量不足 1 例, 投与前の 胸部レ線所見不明 1 例であった（Table 3)。従っ て臨床効果の解析対象は251例 (CTRX 群124例, CTX 群127例）であった。これらを更に群別する と肺炎群145例, 慢性気道感染群106例となった。 また P. aeruginosa が起炎菌とみなされた例につ いては，本剂执よび対照薬剂の抗緑膿菌作用が乏 
Fig. 2 Case distribution

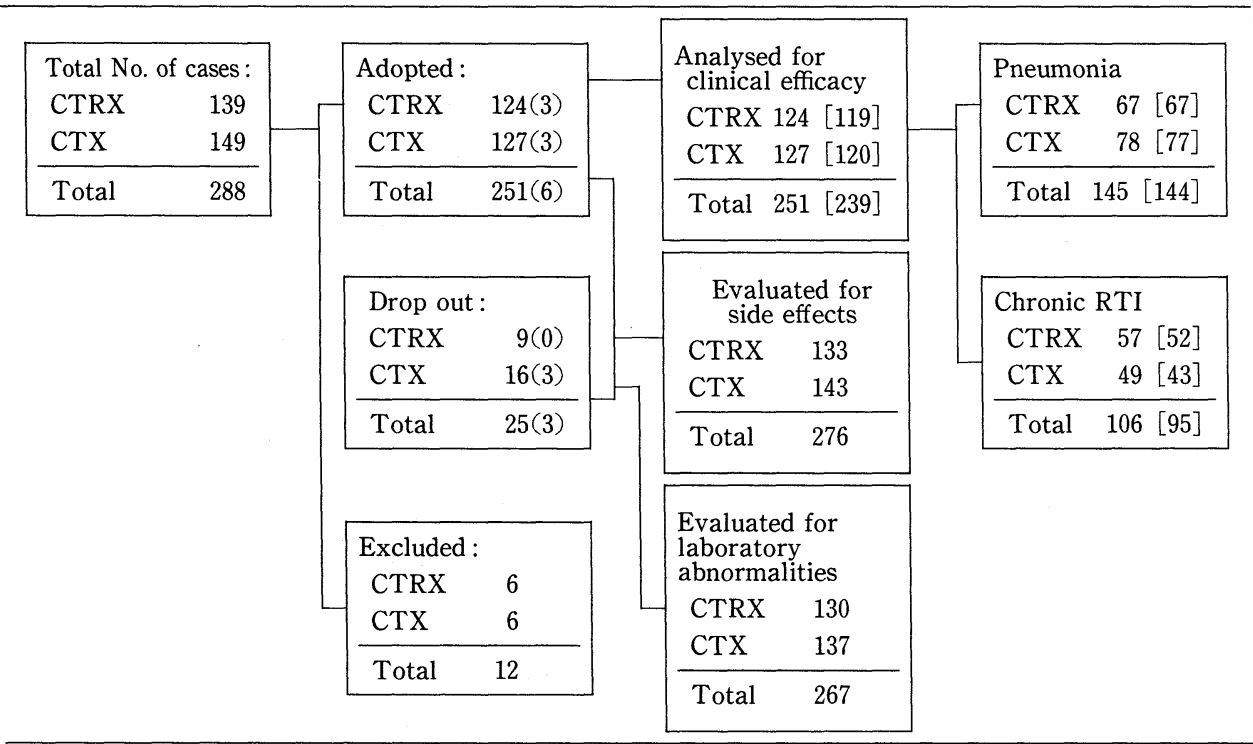

( ) : Laboratory tests were not carried out.

[ ] : Excluding $P$. aeruginosa infection

Table 3 Reasons for exclusion and drop out

\begin{tabular}{|c|c|c|c|c|}
\hline Exclusion & $\begin{array}{l}\text { No. of } \\
\text { cases }\end{array}$ & CTRX & CTX & $\begin{array}{l}\text { Statistical } \\
\text { test }\end{array}$ \\
\hline Severe underlying disease & 9 & 4 & 5 & \multirow{3}{*}{ N.S. } \\
\hline $\begin{array}{l}\text { Combined administration with } \\
\text { other antibiotic or steroid }\end{array}$ & 2 & 2 . & 0 & \\
\hline Death for another reason & 1 & 0 & 1 & \\
\hline Total & 12 & 6 & 6 & \\
\hline Drop out & $\begin{array}{l}\text { No. of } \\
\text { cases }\end{array}$ & CTRX & CTX & $\begin{array}{c}\text { Statistical } \\
\text { test }\end{array}$ \\
\hline Diseases out of the object & 15 & 6 & 9 & \multirow{5}{*}{ N.S. } \\
\hline $\begin{array}{l}\text { Discontinuation of administra- } \\
\text { tion due to side effects }\end{array}$ & 4 & 2 & 2 & \\
\hline Symptoms of infections unclear & 4 & 1 & 3 & \\
\hline Shortage of dose & 1 & 0 & 1 & \\
\hline $\begin{array}{l}\text { Chest X-ray photograph not } \\
\text { taken before treatment }\end{array}$ & 1 & 0 & 1 & \\
\hline Total & 25 & 9 & 16 & \\
\hline
\end{tabular}

しいことから，これらを除いた成績をも別途集計 した.

2. 症例背景因子

臨床効果解析対象例251例（CTRX 群124例 CTX 群127例）の各背景因子について両薬剤群間 の比較を行った。

1）構成疾患
対象とした呼吸器感染症をさらに詳細に群別 し，両薬剤群間で比較した (Table 4)。これら小 群別にみた場合, 疾患構成は両薬剂群へほとんど 均等に分布されており，有意差はみられなかった。

2）年齢，性，体重

対象症例の年齢，性別，体重などの背景因子も 両群間で有意差はみられなかった（Table 5)。 
3）重症度, 基礎疾患·合併症, 前化療, 併用薬 小委員会判定による重症度, 主治医判定による 重症度, 基礎疾患・合併症の有無, 前化療抗生剂 の有無および中止理由, 併用薬の有無とその内容 等について両群間で比較した結果，いずれの諸項 目に扔いても有意差はみられなかった(Table 6).

4) 臨床症状・所見

投与開始前の体温, 咳嗽, 喀痰量, 喀疢性状,

Table 4 Diagnosis of respiratory tract infections judged by committee

\begin{tabular}{lrrr}
\hline \multicolumn{1}{c}{ Diagnosis } & CTRX & CTX & $\begin{array}{c}\text { Statistical } \\
\text { test }\end{array}$ \\
\hline Pneumonia & 64 & 74 & \\
Pulmonary suppuration & 3 & 4 & \\
Chronic bronchitis & 25 & 21 & \\
$\begin{array}{l}\text { Diffuse bronchiolitis } \\
\text { Bronchiectasis with }\end{array}$ & 6 & 6 & \\
$\begin{array}{l}\text { infection } \\
\text { Pulmonary emphysema with }\end{array}$ & 10 & 11 & N.S. \\
$\begin{array}{l}\text { infection } \\
\text { Pulmonary fibrosis with }\end{array}$ & 2 & 1 & \\
infection & & & \\
$\begin{array}{l}\text { Pulmonary tuberculosis } \\
\text { with infection }\end{array}$ & 4 & 4 & \\
$\begin{array}{l}\text { Lung cancer with } \\
\text { infection }\end{array}$ & 5 & 4 & \\
$\begin{array}{l}\text { Pneumonoconiosis with } \\
\text { infection }\end{array}$ & 1 & 0 & \\
\hline \multicolumn{1}{c}{ Total } & 124 & 127 & \\
\hline
\end{tabular}

呼吸困難, 胸痛, 胸部ラ音, 脱水症状, チアノ一 ゼ, 白血球数, 血沈，CRP，血液ガス所見等の有 無や程度を両群間について比較した結果，とくに 有意差はみられなかった（Table 1).

\section{5）胸部レ線所見}

肺炎群に抢ける治療開始前の胸部レ線像につい て，小委員会判定による重症度点数执よびその分 布を両薬剂群間で比較した結果，有意差はみられ なかった（Table 8).

6) 起炎菌

小委員会に打いて起炎菌が確定された症例は97 例 (CTRX 群44例，CTX 群53例)であった。 らち 単独菌感染81例(CTRX34例, CTX47例), 複数菌 感染16例（CTRX 10例，CTX 6 例）であった。

起炎菌の種別では, S. aureus, S. pneumoniae, H. influenzae 等が比較的高頻度に検出されてい たが，その詳細は表にまとめた（Table 9). 両薬 剂群間とくに有意差はみられなかった。

また，当初対象としなかった P. aeruginosa 感 染例12例 (CTRX 群 5 例, CTX 群 7 例) がみられ た.

3. 小委員会判定による臨床効果

1）全例执よび疾患別臨床効果

全例を対象として場合, CTRX 群124例中, 著効

Table 5 Backgrounds of cases

\begin{tabular}{|c|c|c|c|c|c|c|c|c|c|c|}
\hline \multirow{2}{*}{\multicolumn{2}{|c|}{ Backgrounds }} & \multicolumn{3}{|c|}{ All cases } & \multicolumn{3}{|c|}{ Pneumonia } & \multicolumn{3}{|c|}{ Other RTI } \\
\hline & & CTRX & CTX & $\begin{array}{c}\text { Statistical } \\
\text { test }\end{array}$ & CTRX & CTX & $\begin{array}{c}\text { Statistical } \\
\text { test }\end{array}$ & CTRX & CTX & $\begin{array}{c}\text { Statistical } \\
\text { test }\end{array}$ \\
\hline \multicolumn{2}{|c|}{ No. of cases } & 124 & 127 & & 67 & 78 & & 57 & 49 & \\
\hline \multirow{2}{*}{ Sex } & Male & 69 & 76 & \multirow{2}{*}{ N.S. } & 32 & 45 & \multirow{2}{*}{ N.S. } & 37 & 31 & \multirow{2}{*}{ N.S. } \\
\hline & Female & 55 & 51 & & 35 & 33 & & 20 & 18 & \\
\hline \multirow{6}{*}{ Age } & -39 & 14 & 17 & \multirow{6}{*}{ N.S. } & 9 & 14 & \multirow{6}{*}{ N.S. } & 5 & 3 & \multirow{6}{*}{ N.S. } \\
\hline & $40-49$ & 17 & 14 & & 13 & 11 & & 4 & 3 & \\
\hline & $50-59$ & 19 & 23 & & 12 & 13 & & 7 & 10 & \\
\hline & $60-69$ & 32 & 35 & & 15 & 18 & & 17 & 17 & \\
\hline & $70-79$ & 31 & 30 & & 12 & 16 & & 19 & 14 & \\
\hline & $80-$ & 11 & 8 & & 6 & 6 & & 5 & 2 & \\
\hline \multirow{6}{*}{$\begin{array}{l}\text { Body } \\
\text { weight } \\
\text { (kg) }\end{array}$} & -39 & 19 & 24 & \multirow{6}{*}{ N.S. } & 6 & 10 & \multirow{6}{*}{ N.S. } & 13 & 14 & \multirow{6}{*}{ N.S. } \\
\hline & $40-49$ & 41 & 38 & & 22 & 24 & & 19 & 14 & \\
\hline & $50-59$ & 36 & 38 & & 22 & 25 & & 14 & 13 & \\
\hline & $60-69$ & 20 & 19 & & 11 & 14 & & 9 & 5 & \\
\hline & $70-$ & 7 & 5 & & 6 & 4 & & 1 & 1 & \\
\hline & unknown & 1 & 3 & & 0 & 1 & & 1 & 2 & \\
\hline
\end{tabular}


Table 6 Backgrounds of cases

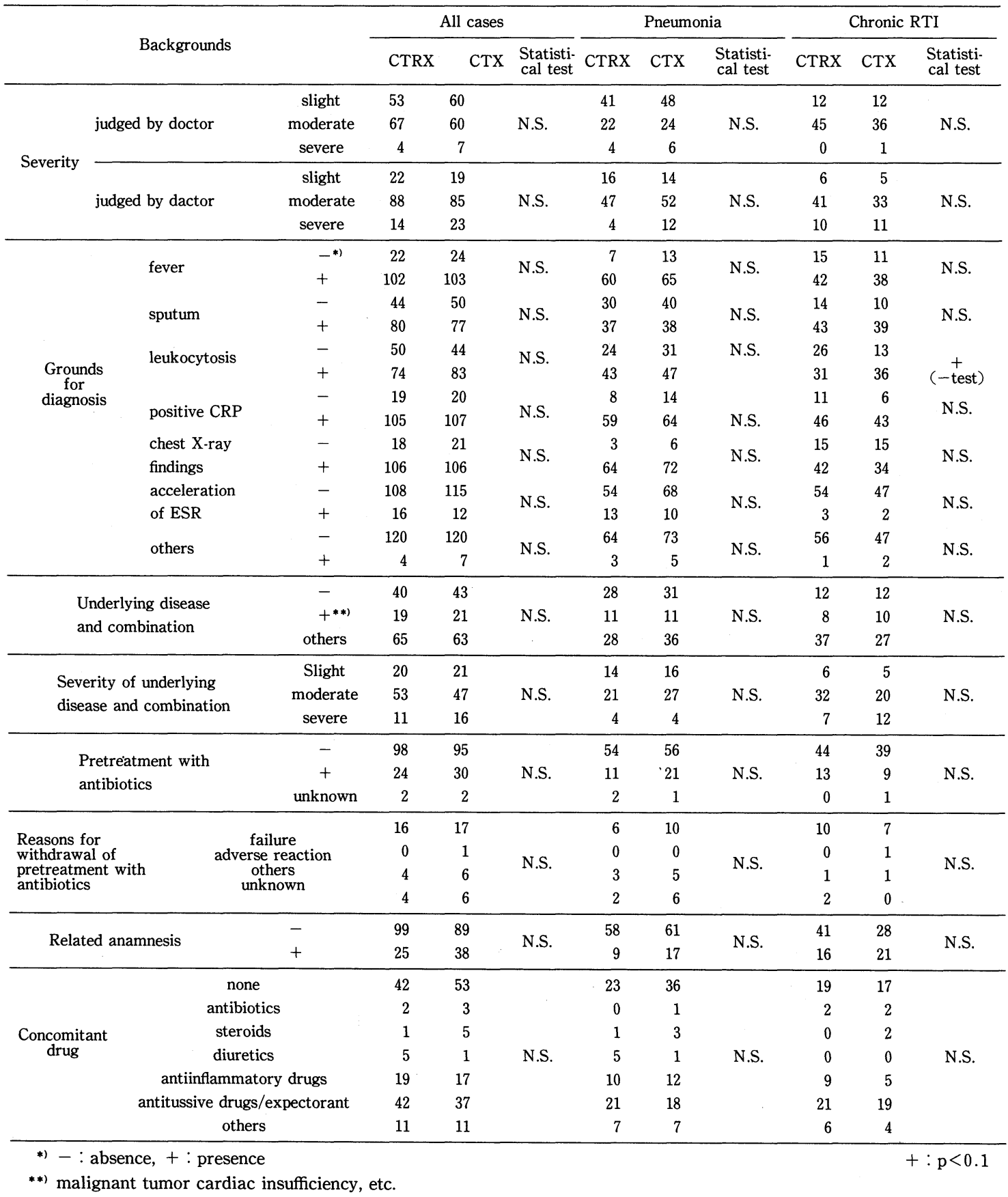

4 例, 有効 96 例, やや有効 13 例, 無効 11 例で有効 率 $81 \%$ ，CTX 群127例中，著効 3 例，有効 91 例， やや有効 12 例，無効21例，有効率74\%であり，両 群間に有意差はみられなかった。
また, 肺炎例では CTRX 群67例中著効 2 例, 有 効 51 例，やや有効 8 例，無効 6 例，有効率 $79 \%$, 一方 CTX 群78例中著効 1 例, 有効60例, pや有効 7 例, 無効 10 例, 有効率 $78 \%$ であり，両群間に有 
Table 7 Initial symptoms and findings

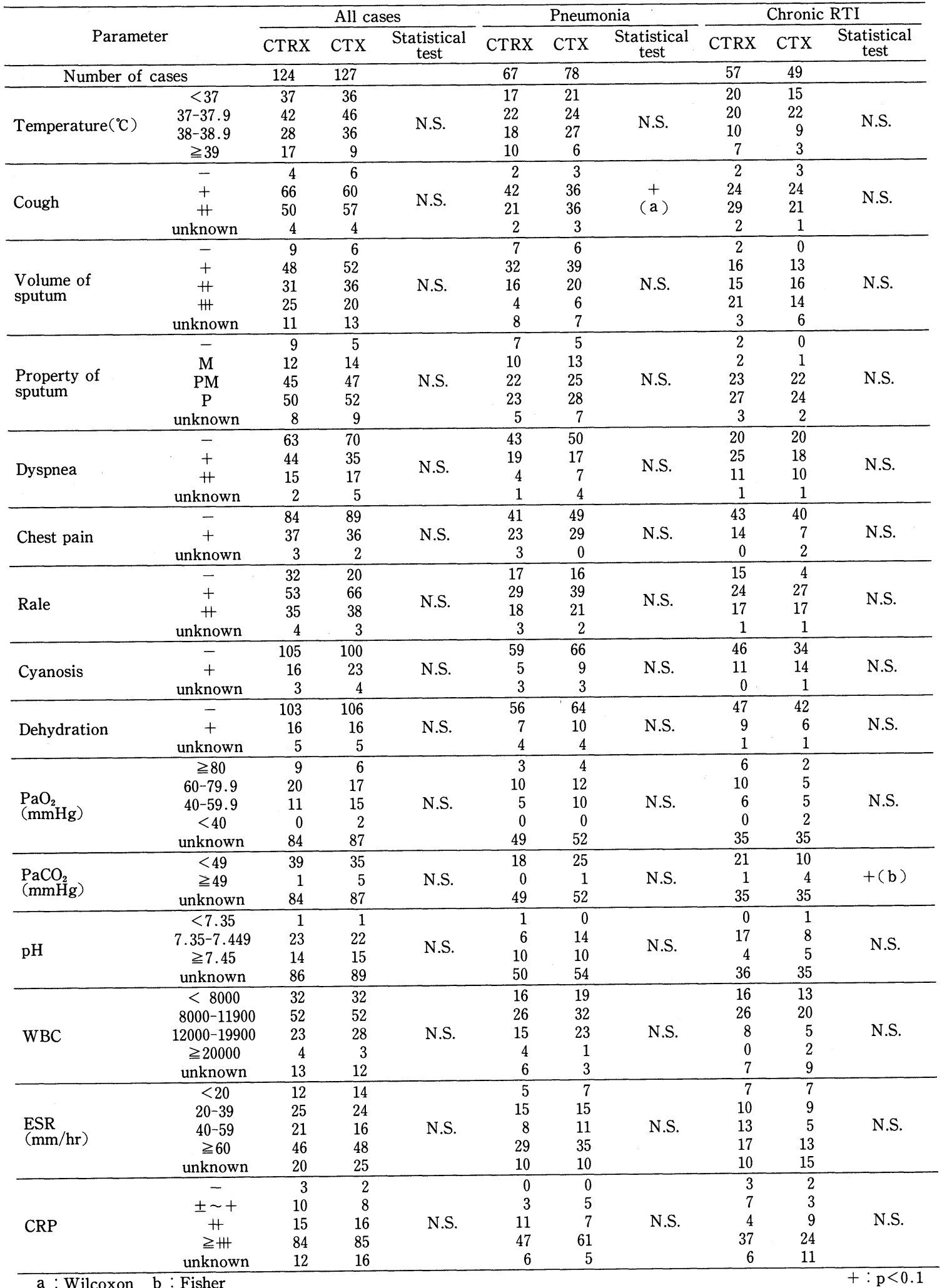


意差はみられなかった。

慢性気道感染例においては, CTRX 群57例中, 著効 2 例, 有効 45 例，やや有効 5 例，無効 5 例で 有効率 $82 \%$, 一方 CTX 群49例では, 著効 2 例, 有 効 31 例, やや有効 5 例, 無効 11 例で有効率 $67 \%$ で あった。すなわち，慢性気道感染症を対象とした 場合，CTRX 群では CTX 群に比しすぐれた傾向 が得られた（Table 10）。

な拉，P. aeruginosa 感染例 (CTRX 群 7 例， CTX 群 5 例)を除いて観察すると, 慢性気道感染 例での有効率は CTRX 群で85\%，CTX 群で72\% になり, 先にみられた傾向差はなみられなかった。

2）重症度別臨床効果

Table 8 Initial chest X-ray findings (pneumonia)

\begin{tabular}{ccccc}
\hline Degree & $\begin{array}{c}\text { Number } \\
\text { of } \\
\text { cases }\end{array}$ & CTRX & CTX & $\begin{array}{c}\text { Statis- } \\
\text { tical } \\
\text { test }\end{array}$ \\
\hline 0 & 0 & 0 & 0 & \\
1 & 1 & 1 & 0 & \\
2 & 19 & 8 & 11 & \\
3 & 42 & 22 & 20 & \\
4 & 30 & 12 & 18 & N.S. \\
5 & 18 & 6 & 12 & \\
6 & 16 & 10 & 6 & \\
7 & 12 & 7 & 5 & \\
8 & 6 & 1 & 5 & \\
9 & 1 & 0 & 1 & \\
10 & 0 & 0 & 0 & \\
\hline Total & 145 & 67 & 78 & \\
\hline
\end{tabular}

全例を重症度で層別すると，軽症例は CTRX 群53例, CTX 群60例であり, この層に沶ける臨床 効果は前者で $81 \%$, 後者で90\%であり, CTX 群に

Table 9 Causative bacteria

\begin{tabular}{|c|c|c|c|c|c|c|}
\hline & & & $\begin{array}{c}\text { Number } \\
\text { of } \\
\text { cases }\end{array}$ & CTRX & CTX & $\begin{array}{c}\text { Statis- } \\
\text { tical } \\
\text { test }\end{array}$ \\
\hline \multicolumn{3}{|c|}{ Single infection } & 81 & 34 & 47 & \\
\hline \multicolumn{3}{|c|}{ Mixed infection } & 16 & 10 & 6 & N.S. \\
\hline \multirow{14}{*}{ 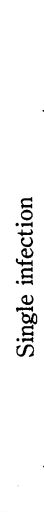 } & \multirow{3}{*}{ GPC } & S. aureus & 10 & 5 & 5 & \multirow{13}{*}{ N.S. } \\
\hline & & S. pneumoniae & 15 & 8 & 7 & \\
\hline & & S. pyogenes & 2 & 1 & 1 & \\
\hline & \multirow{11}{*}{ GNR } & E. coli & 3 & 2 & 1 & \\
\hline & & $K$. pneumoniae & 7 & 2 & 5 & \\
\hline & & Klebisella spp. & 4 & 0 & 4 & \\
\hline & & H. influenzae & 23 & 9 & 14 & \\
\hline & & Haemophilus spp. & 2 & 1 & 1 & \\
\hline & & Citrobacter spp. & 1 & 0 & 1 & \\
\hline & & Enterobacter spp. & 2 & 0 & 2 & \\
\hline & & Serratia $s p p$ & 1 & 1 & 0 & \\
\hline & & P. aeruginosa & 9 & 3 & 6 & \\
\hline & & Other GNR & 2 & 2 & 0 & \\
\hline & & Subtotal & 81 & 34 & 47 & \\
\hline \multirow{13}{*}{ 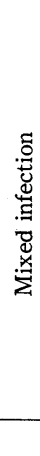 } & S. aure & $u s+$ E. coli & 1 & 1 & 0 & \multirow{12}{*}{ N.S. } \\
\hline & S. aure & $u s+K$. pneumoniae & 1 & 1 & 0 & \\
\hline & S. aur & $u s+H$. aphrophilus & 1 & 0 & 1 & \\
\hline & S. aure & $u s+E$. cloacae & 1 & 0 & 1 & \\
\hline & S. aure & $u s+P$. aeruginosa & 1 & 1 & 0 & \\
\hline & S. pne & ımoniae $+E$. coli & 1 & 1 & 0 & \\
\hline & S. pne & imoniae $+H$. influenzae & 4 & 3 & 1 & \\
\hline & E. coli & $+K$. pneumoniae & 2 & 2 & 0 & \\
\hline & E. coli & $+E$. aerogenes & 1 & 0 & 1 & \\
\hline & K. pne & umoniae $+H$. influenzae & 1 & 0 & 1 & \\
\hline & H. inf & uenzae $+P$. aeruginosa & 2 & 1 & 1 & \\
\hline & & Subtotal & 16 & 10 & 6 & \\
\hline & & Total & 97 & 44 & 53 & \\
\hline
\end{tabular}

Table 10 Clinical efficacy judged by committee

\begin{tabular}{|c|c|c|c|c|c|c|c|c|}
\hline & Drug & $\begin{array}{l}\text { Number } \\
\text { of cases }\end{array}$ & $\begin{array}{l}\text { Exce- } \\
\text { llent }\end{array}$ & Good & Fair & Poor & $\begin{array}{l}\text { Efficacy } \\
\text { rate }\end{array}$ & $\begin{array}{l}\text { Statistical } \\
\text { test }\end{array}$ \\
\hline \multirow{2}{*}{ All cases } & CTRX & $\begin{array}{c}124 \\
(119)\end{array}$ & $\begin{array}{c}4 \\
(4)\end{array}$ & $\begin{array}{c}96 \\
(93)\end{array}$ & $\begin{array}{l}13 \\
\text { (13) }\end{array}$ & $\begin{array}{l}11 \\
(9)\end{array}$ & $\begin{array}{l}81 \% \\
(82 \%)\end{array}$ & \multirow{2}{*}{ (N.S. } \\
\hline & CTX & $\begin{array}{c}127 \\
(120)\end{array}$ & $\begin{array}{c}3 \\
(3)\end{array}$ & $\begin{array}{c}91 \\
(88) \\
\end{array}$ & $\begin{array}{c}12 \\
(12)\end{array}$ & (17) & $\begin{array}{c}74 \% \\
(76 \%)\end{array}$ & \\
\hline \multirow{2}{*}{ Pneumonia } & CTRX & $\begin{array}{c}67 \\
(67)\end{array}$ & $\stackrel{2}{(2)}$ & $\begin{array}{c}51 \\
(51)\end{array}$ & $\begin{array}{c}8 \\
(8)\end{array}$ & $\begin{array}{c}6 \\
(6)\end{array}$ & $\begin{array}{c}79 \% \\
(79 \%)\end{array}$ & \multirow{2}{*}{ N.S. } \\
\hline & CTX & $\begin{array}{c}78 \\
(77)\end{array}$ & (1) & $\begin{array}{c}60 \\
(59)\end{array}$ & $\begin{array}{c}7 \\
(7)\end{array}$ & $\begin{array}{c}10 \\
(10)\end{array}$ & $\begin{array}{c}78 \% \\
(78 \%)\end{array}$ & \\
\hline \multirow{2}{*}{ Chronic RTI } & CTRX & $\begin{array}{c}57 \\
(52)\end{array}$ & $\stackrel{2}{(2)}$ & $\begin{array}{c}45 \\
(42)\end{array}$ & $\begin{array}{c}5 \\
(5)\end{array}$ & $\begin{array}{c}5 \\
(3)\end{array}$ & $\begin{array}{l}82 \% \\
(85 \%)\end{array}$ & \multirow{2}{*}{$\begin{array}{c}\text { CTRX }>\text { CTX } \\
+[\text { Wilcoxon }] \\
\text { (N.S.) }\end{array}$} \\
\hline & CTX & $\begin{array}{c}49 \\
(43)\end{array}$ & $\stackrel{2}{(2)}$ & $\begin{array}{c}31 \\
(29)\end{array}$ & $\begin{array}{l}5 \\
(5)\end{array}$ & 11 & $\begin{array}{c}67 \% \\
(72 \%)\end{array}$ & \\
\hline
\end{tabular}


Table 11 Clinical efficacy classified by severity (judged by committee)

\begin{tabular}{|c|c|c|c|c|c|c|c|c|c|c|c|}
\hline & & Drug & $\begin{array}{l}\text { Number } \\
\text { of cases }\end{array}$ & $\begin{array}{l}\text { Exce- } \\
\text { llent }\end{array}$ & Good & Fair & Poor & $\begin{array}{l}\text { Efficacy } \\
\text { rate }\end{array}$ & $\begin{array}{l}\text { Wilcoxon } \\
\text { test }\end{array}$ & $\begin{array}{l}\text { Fisher or } \\
\text { Excellent }\end{array}$ & $\begin{array}{l}\mathrm{X}^{2} \text {-test } \\
\text { Excellent } \\
\quad+\text { Good }\end{array}$ \\
\hline \multirow{6}{*}{ All cases } & \multirow{2}{*}{ Slight } & CTRX & $\begin{array}{c}53 \\
(52)\end{array}$ & $\stackrel{1}{(1)}$ & $\begin{array}{c}42 \\
(42)\end{array}$ & $\begin{array}{c}5 \\
(5)\end{array}$ & $\begin{array}{c}5 \\
(4)\end{array}$ & $\begin{array}{c}81 \% \\
(83 \%)\end{array}$ & N.S. & N.S & N.S. \\
\hline & & CTX & $\begin{array}{c}60 \\
(60)\end{array}$ & (1) & $\begin{array}{c}53 \\
(53)\end{array}$ & $\begin{array}{c}4 \\
(4)\end{array}$ & $\stackrel{2}{(2)}$ & $\begin{array}{c}90 \% \\
(90 \%)\end{array}$ & (N.S.) & (N.S.) & (N.S.) \\
\hline & \multirow{2}{*}{ Moderate } & CTRX & $\begin{array}{c}67 \\
(63)\end{array}$ & $\begin{array}{c}3 \\
(3)\end{array}$ & $\begin{array}{c}51 \\
(48)\end{array}$ & $\begin{array}{c}7 \\
(7)\end{array}$ & $\begin{array}{c}6 \\
(5)\end{array}$ & $\begin{array}{l}81 \% \\
(81 \%)\end{array}$ & $*$ & N.S. & ${ }^{*}$ \\
\hline & & CTX & $\begin{array}{c}60 \\
(53) \\
\end{array}$ & $\begin{array}{c}2 \\
(2)\end{array}$ & $\begin{array}{c}35 \\
(32) \\
\end{array}$ & $\begin{array}{c}8 \\
(8)\end{array}$ & $\begin{array}{l}15 \\
\text { (11) }\end{array}$ & $\begin{array}{c}62 \% \\
(64 \%)\end{array}$ & $(*)$ & (N.S.) & $(+)$ \\
\hline & \multirow{2}{*}{ Severe } & CTRX & $\begin{array}{c}4 \\
(4)\end{array}$ & $\begin{array}{c}0 \\
(0)\end{array}$ & $\begin{array}{c}3 \\
(3)\end{array}$ & (1) & $\begin{array}{c}0 \\
(0)\end{array}$ & $\begin{array}{c}75 \% \\
(75 \%)\end{array}$ & N.S. & N.S & N.S. \\
\hline & & CTX & $\begin{array}{c}7 \\
(7) \\
\end{array}$ & $\begin{array}{c}0 \\
(0) \\
\end{array}$ & $\begin{array}{c}3 \\
(3) \\
\end{array}$ & $\begin{array}{c}0 \\
(0)\end{array}$ & $\begin{array}{c}4 \\
(4) \\
\end{array}$ & $\begin{array}{c}43 \% \\
(43 \%) \\
\end{array}$ & (N.S.) & (N.S.) & (N.S.) \\
\hline \multirow{6}{*}{ Pneumonia } & \multirow{2}{*}{ Slight } & CTRX & $\begin{array}{c}41 \\
(41)\end{array}$ & $\stackrel{1}{(1)}$ & $\begin{array}{c}32 \\
(32)\end{array}$ & $\begin{array}{c}4 \\
(4)\end{array}$ & $\begin{array}{c}4 \\
(4)\end{array}$ & $\begin{array}{l}80 \% \\
(80 \%)\end{array}$ & N.S. & N.S & N.S. \\
\hline & & CTX & $\begin{array}{c}48 \\
(48) \\
\end{array}$ & (1) & $\begin{array}{c}42 \\
(42) \\
\end{array}$ & $\begin{array}{c}3 \\
(3) \\
\end{array}$ & $\stackrel{2}{(2)}$ & $\begin{array}{c}90 \% \\
(90 \%) \\
\end{array}$ & (N.S.) & (N.S.) & (N.S.) \\
\hline & \multirow{2}{*}{ Moderate } & CTRX & $\begin{array}{c}22 \\
(22)\end{array}$ & (1) & $\begin{array}{c}16 \\
(16)\end{array}$ & $\begin{array}{c}3 \\
(3)\end{array}$ & $\begin{array}{c}2 \\
(2)\end{array}$ & $\begin{array}{c}77 \% \\
(77 \%)\end{array}$ & NS. & N.S. & N.S. \\
\hline & & CTX & $\stackrel{24}{(23)}$ & $\stackrel{0}{(0)}$ & $\begin{array}{c}15 \\
(14)\end{array}$ & $\begin{array}{c}4 \\
(4)\end{array}$ & $\begin{array}{c}5 \\
(5)\end{array}$ & $\begin{array}{c}63 \% \\
(61 \%) \\
\end{array}$ & (N.S.) & (N.S.) & (N.S.) \\
\hline & \multirow{2}{*}{ Severe } & CTRX & $\begin{array}{c}4 \\
(4)\end{array}$ & $\begin{array}{c}0 \\
(0)\end{array}$ & $\begin{array}{c}3 \\
(3)\end{array}$ & (1) & $\begin{array}{c}0 \\
(0)\end{array}$ & $\begin{array}{c}75 \% \\
(75 \%)\end{array}$ & N.S. & N.S & N.S. \\
\hline & & CTX & $\begin{array}{c}6 \\
(6) \\
\end{array}$ & $\begin{array}{c}0 \\
(0)\end{array}$ & $\begin{array}{c}3 \\
(3) \\
\end{array}$ & $\begin{array}{c}0 \\
(0)\end{array}$ & $\begin{array}{c}3 \\
(3) \\
\end{array}$ & $\begin{array}{c}50 \% \\
(50 \%) \\
\end{array}$ & (N.S.) & (N.S.) & (N.S.) \\
\hline \multirow{6}{*}{$\underset{\text { RTI }}{\text { Chronic }}$} & \multirow{2}{*}{ Slight } & CTRX & (11) & $\stackrel{0}{(0)}$ & $\begin{array}{c}10 \\
(10)\end{array}$ & (1) & $\begin{array}{l}1 \\
(0)\end{array}$ & $\begin{array}{l}83 \% \\
(91 \%)\end{array}$ & N.S. & N.S & N.S. \\
\hline & & CTX & $\begin{array}{c}12 \\
(12) \\
\end{array}$ & $\begin{array}{c}0 \\
(0) \\
\end{array}$ & (11) & (1) & $\begin{array}{c}0 \\
(0) \\
\end{array}$ & $\begin{array}{r}92 \% \\
(92 \%) \\
\end{array}$ & (N.S.) & (N.S.) & (N.S.) \\
\hline & \multirow{2}{*}{ Moderate } & CTRX & $\begin{array}{c}45 \\
(41)\end{array}$ & $\stackrel{2}{(2)}$ & $\begin{array}{c}35 \\
(32)\end{array}$ & $\begin{array}{c}4 \\
(4)\end{array}$ & $\begin{array}{l}4 \\
(3)\end{array}$ & $\begin{array}{l}82 \% \\
(83 \%)\end{array}$ & + & N.S. & $*$ \\
\hline & & CTX & $\begin{array}{c}36 \\
(30)\end{array}$ & $\begin{array}{c}2 \\
(2)\end{array}$ & $\begin{array}{c}20 \\
(18)\end{array}$ & $\begin{array}{c}4 \\
(4) \\
\end{array}$ & $\begin{array}{l}10 \\
(6)\end{array}$ & $\begin{array}{c}61 \% \\
(67 \%)\end{array}$ & (N.S.) & (N.S.) & (N.S.) \\
\hline & \multirow{2}{*}{ Severe } & CTRX & $\stackrel{0}{(0)}$ & & & & & & & & \\
\hline & & CTX & (1) & $\begin{array}{c}0 \\
(0)\end{array}$ & $\begin{array}{c}0 \\
(0)\end{array}$ & $\begin{array}{c}0 \\
(0)\end{array}$ & (1) & $\begin{array}{l}0 \% \\
(0 \%)\end{array}$ & & & \\
\hline
\end{tabular}

高い有効率が得られたが有意差はみられなかっ た. 中等症例では, CTRX67例中有効以上54例, 有効率 $81 \%$ ，一方 CTX 群では60例中有効以上 37 例, 有効率 $62 \%$ と示され, CTRX 群に拈ける成績 は CTX 群のそれに比し有意にすぐれていた。ま たP. aeruginosa 感染例を除いて集計してもこの 層で CTRX 群は CTX 群に比し有意にすぐれた 成績が得られた。重症群では両群とも症例数が少 なく，また有意差もみられなかった。さらにこ れらの成績を肺炎例拉よび慢性気道感染例に分け て観察すると, 慢性気道感染例の中等度層に打い て CTRX 群が CTX 群に比し, 有意にすぐれてい たが，P. aeruginosa 感染例を除いて観察すると，
有意差はみられなかった（Table 11）。

3）基礎疾患・合併症の有無と臨床効果

基礎疾患・合併症を有する例は，これを感染症 の予後に影響を及ぼすと考兄られるもの（悪性腫 瘍, 免疫防御機能低下因子, 心不全, 脳卒中等） をかりにA群合併症とし，そうでないと考えるも のをB群合併症とし，それぞれ分けて観察した。 両薬剤群間に扔いて臨床効果を比較すると, B 群 合併症群に执いて CTRX 群が CTX 群に比し有 意にすぐれてた成績が得られていた. P. aeruginosa 例を除いても，これら有意差がみられた。しかし ながら「B群合併症」といら臨床的意義はきわめて 不明確であり, 従って前項に扣ける重症度が中等 
Table 12 Clinical efficacy classified by presence of underlying disease or complication (judged by committee)

\begin{tabular}{|c|c|c|c|c|c|c|c|c|c|c|c|}
\hline & & Drug & $\begin{array}{l}\text { Number } \\
\text { of cases }\end{array}$ & $\begin{array}{l}\text { Exce- } \\
\text { llent }\end{array}$ & Good & Fair & Poor & $\begin{array}{l}\text { Efficacy } \\
\text { rate }\end{array}$ & $\begin{array}{c}\text { Wilcoxon } \\
\text { test }\end{array}$ & $\begin{array}{l}\text { Fisher or } \\
\text { Excellent }\end{array}$ & $\begin{array}{l}\mathrm{X}^{2} \text {-test } \\
\text { Excellent } \\
\quad+\text { Good }\end{array}$ \\
\hline \multirow{6}{*}{ All cases } & \multirow{2}{*}{ No. } & CTRX & $\begin{array}{c}40 \\
(38)\end{array}$ & (1) & $\begin{array}{c}30 \\
(29)\end{array}$ & $\begin{array}{c}5 \\
(5)\end{array}$ & $\begin{array}{c}4 \\
(3)\end{array}$ & $\begin{array}{c}78 \% \\
(79 \%)\end{array}$ & N.S. & N.S & N.S. \\
\hline & & CTX & $\begin{array}{c}43 \\
(41)\end{array}$ & $\stackrel{2}{(2)}$ & $\begin{array}{c}33 \\
(33)\end{array}$ & $\stackrel{2}{(2)}$ & $\begin{array}{c}6 \\
(4)\end{array}$ & $\begin{array}{l}81 \% \\
(85 \%)\end{array}$ & (N.S.) & (N.S.) & (N.S.) \\
\hline & \multirow{2}{*}{$\begin{array}{l}\text { Malignant } \\
\text { tumor, cardiac } \\
\text { insufficiency, } \\
\text { etc. }\end{array}$} & CTRX & $\begin{array}{c}19 \\
(19)\end{array}$ & (1) & (11) & $\stackrel{4}{(4)}$ & $\begin{array}{c}3 \\
(3)\end{array}$ & $\begin{array}{c}63 \% \\
(63 \%)\end{array}$ & N.S. & N.S. & N.S. \\
\hline & & CTX & $\begin{array}{c}21 \\
(19)\end{array}$ & $\begin{array}{c}0 \\
(0)\end{array}$ & $\begin{array}{c}14 \\
\text { (13) }\end{array}$ & (1) & $\begin{array}{c}6 \\
(5)\end{array}$ & $\begin{array}{c}67 \% \\
(68 \%)\end{array}$ & (N.S.) & (N.S.) & (N.S.) \\
\hline & \multirow{2}{*}{ Others } & CTRX & $\begin{array}{c}65 \\
(62)\end{array}$ & $\begin{array}{c}2 \\
(2)\end{array}$ & $\begin{array}{c}55 \\
(53)\end{array}$ & $\begin{array}{c}4 \\
(4)\end{array}$ & $\begin{array}{l}4 \\
(3)\end{array}$ & $\begin{array}{c}88 \% \\
(89 \%)\end{array}$ & * & N.S & $*$ \\
\hline & & CTX & $\begin{array}{c}63 \\
(60)\end{array}$ & (1) & $\begin{array}{c}44 \\
(42)\end{array}$ & $\begin{array}{c}9 \\
(9)\end{array}$ & $\begin{array}{c}9 \\
(8)\end{array}$ & $\begin{array}{c}71 \% \\
(72 \%)\end{array}$ & (*) & (N.S.) & $(*)$ \\
\hline \multirow{6}{*}{ Pneumonia } & \multirow{2}{*}{ No. } & CTRX & $\begin{array}{c}28 \\
(28)\end{array}$ & (1) & $\begin{array}{l}19 \\
(19)\end{array}$ & $\begin{array}{c}5 \\
(5)\end{array}$ & $\begin{array}{c}3 \\
(3)\end{array}$ & $\begin{array}{c}71 \% \\
(71 \%)\end{array}$ & N.S. & N.S & N.S. \\
\hline & & CTX & $\begin{array}{c}31 \\
(31)\end{array}$ & (1) & $\begin{array}{c}26 \\
(26)\end{array}$ & $\begin{array}{c}2 \\
(2)\end{array}$ & (2) & $\begin{array}{c}87 \% \\
(87 \%)\end{array}$ & (N.S.) & (N.S.) & (N.S.) \\
\hline & \multirow{2}{*}{$\begin{array}{l}\text { Malignant } \\
\text { tumor, cardiac } \\
\text { insufficiency, } \\
\text { etc. }\end{array}$} & CTRX & (11) & $\stackrel{0}{(0)}$ & $\begin{array}{c}7 \\
(7)\end{array}$ & $\begin{array}{c}3 \\
(3)\end{array}$ & $\begin{array}{l}1 \\
(1)\end{array}$ & $\begin{array}{c}64 \% \\
(64 \%)\end{array}$ & N.S. & N.S. & N.S. \\
\hline & & CTX & $\begin{array}{c}11 \\
(10)\end{array}$ & $\begin{array}{c}0 \\
(0)\end{array}$ & $\begin{array}{c}7 \\
(6)\end{array}$ & (1) & (3) & $\begin{array}{c}64 \% \\
(60 \%)\end{array}$ & (N.S.) & (N.S.) & (N.S.) \\
\hline & \multirow{2}{*}{ Others } & CTRX & $\begin{array}{c}28 \\
(28)\end{array}$ & (1) & $\begin{array}{c}25 \\
(25)\end{array}$ & $\stackrel{0}{(0)}$ & $\stackrel{2}{(2)}$ & $\begin{array}{c}93 \% \\
(93 \%)\end{array}$ & * & N.S & + \\
\hline & & CTX & $\begin{array}{c}36 \\
(36)\end{array}$ & $\begin{array}{c}0 \\
(0)\end{array}$ & $\begin{array}{c}27 \\
(27)\end{array}$ & $\begin{array}{c}4 \\
(4)\end{array}$ & $\begin{array}{c}5 \\
(5)\end{array}$ & $\begin{array}{c}75 \% \\
(75 \%)\end{array}$ & $(*)$ & (N.S.) & $(+)$ \\
\hline \multirow{6}{*}{$\underset{\text { RTI }}{\text { Chronic }}$} & \multirow{2}{*}{ No. } & CTRX & $\begin{array}{c}12 \\
(10)\end{array}$ & $\begin{array}{c}0 \\
(0)\end{array}$ & $\begin{array}{c}11 \\
(10)\end{array}$ & $\begin{array}{c}0 \\
(0)\end{array}$ & $\begin{array}{c}1 \\
(0)\end{array}$ & $\begin{array}{c}92 \% \\
(100 \%)\end{array}$ & N.S. & N.S & N.S. \\
\hline & & СТX & $\begin{array}{c}12 \\
(10)\end{array}$ & (1) & $\begin{array}{c}7 \\
(7)\end{array}$ & $\begin{array}{c}0 \\
(0)\end{array}$ & $\begin{array}{c}4 \\
(2)\end{array}$ & $\begin{array}{c}67 \% \\
(80 \%)\end{array}$ & (N.S.) & (N.S.) & (N.S.) \\
\hline & \multirow{2}{*}{$\begin{array}{l}\text { Malignant } \\
\text { tumor, cardiac } \\
\text { insufficiency, } \\
\text { etc. }\end{array}$} & CTRX & $\begin{array}{c}8 \\
(8)\end{array}$ & (1) & $\begin{array}{c}4 \\
(4)\end{array}$ & (1) & $\begin{array}{c}2 \\
(2)\end{array}$ & $\begin{array}{c}63 \% \\
(63 \%)\end{array}$ & N.S. & N.S. & N.S. \\
\hline & & CTX & $\begin{array}{l}10 \\
(9)\end{array}$ & $\stackrel{0}{(0)}$ & $\begin{array}{c}7 \\
(7)\end{array}$ & $\begin{array}{c}0 \\
(0)\end{array}$ & $\begin{array}{c}3 \\
(2)\end{array}$ & $\begin{array}{c}70 \% \\
(78 \%)\end{array}$ & (N.S.) & (N.S.) & (N.S.) \\
\hline & \multirow{2}{*}{ Others } & CTRX & $\begin{array}{c}37 \\
(34)\end{array}$ & (1) & $\begin{array}{c}30 \\
(28)\end{array}$ & $\begin{array}{c}4 \\
(4)\end{array}$ & (1) & $\begin{array}{c}84 \% \\
(85 \%)\end{array}$ & N.S. & N.S. & N.S. \\
\hline & & CTX & $\begin{array}{c}27 \\
(24)\end{array}$ & (1) & $\stackrel{17}{(15)}$ & $\begin{array}{c}5 \\
(5)\end{array}$ & $\begin{array}{c}4 \\
(3)\end{array}$ & $\begin{array}{c}67 \% \\
(67 \%)\end{array}$ & (N.S.) & (N.S.) & (N.S.) \\
\hline
\end{tabular}

度の例が，この群層を構成しているものと理解さ れた (Table 12).

4）投与前抗生剂の有無と臨床効果

本剂投与前に抗生剂が投与されていた例は54例 あり，らち CTRX 群24例, CTX 群30例であった。 両群間に拈ける臨床効果をみると慢性気道感染例 に陉いて CTRX 群が CTX 群に比し有意にすぐ れた効果が得られた.しかしながら P. aeruginosa 感染例を除外するとこの群に括ける有意差はみら れなかった。また肺炎例に拈いて有意差はみられ なかったが, CTRX 群で有効率が高く, この両者 に拈ける差が全例に打いて反映したものと示唆さ れた（Table 13）。
4. 小委員会判定による細菌学的効果

起炎菌が確定された97例について, 小委員会に より判定された両薬剤群間の細菌学的効果を比較 した.

全例を対象とした場合, CTRX 群44例中，消失 35 例で消失率 $80 \%, \mathrm{CTX}$ 群53例中, 消失 42 例を消 失率79\%であり, 両群間に有意差はみられなかっ た。これらの成績を単独感染例と混合感染例にわ けて観察すると, 単独感染例では CTRX 群より CTX 群の消失率が高く, 混合感染例では逆に CTX 群より CTRX 群で高い消失率が得られた (Table 14).

5. 臨床症状, 胸部レ線所見の改善度 
Table 13 Clinical efficacy classified by presence of use of antibiotics before treatment (judged by committee)

\begin{tabular}{|c|c|c|c|c|c|c|c|c|c|c|c|}
\hline & & Drug & $\begin{array}{l}\text { Number } \\
\text { of cases }\end{array}$ & $\begin{array}{l}\text { Exce- } \\
\text { llent }\end{array}$ & Good & Fair & Poor & $\begin{array}{l}\text { Efficacy } \\
\text { rate }\end{array}$ & $\begin{array}{c}\text { Wilcoxon } \\
\text { test }\end{array}$ & $\begin{array}{l}\text { Fisher or } \\
\text { Excellent }\end{array}$ & $\begin{array}{l}\mathrm{X}^{2} \text {-test } \\
\text { Excellent } \\
\quad+\text { Good }\end{array}$ \\
\hline \multirow{4}{*}{ All cases } & \multirow{2}{*}{ No. } & CTRX & $\begin{array}{c}98 \\
(95)\end{array}$ & $\begin{array}{c}4 \\
(4)\end{array}$ & $\begin{array}{c}75 \\
(72)\end{array}$ & $\begin{array}{l}10 \\
(10)\end{array}$ & $\begin{array}{c}9 \\
(9)\end{array}$ & $\begin{array}{l}81 \% \\
(80 \%)\end{array}$ & N.S. & N.S & N.S. \\
\hline & & CTX & $\begin{array}{c}95 \\
(92)\end{array}$ & $\begin{array}{c}3 \\
(3)\end{array}$ & $\begin{array}{c}73 \\
(70)\end{array}$ & $\begin{array}{c}8 \\
(8)\end{array}$ & (11) & $\begin{array}{l}80 \% \\
(79 \%)\end{array}$ & (N.S.) & (N.S.) & (N.S.) \\
\hline & \multirow{2}{*}{ Yes. } & CTRX & $\begin{array}{c}24 \\
(22)\end{array}$ & $\begin{array}{c}0 \\
(0)\end{array}$ & $\begin{array}{c}19 \\
(19)\end{array}$ & $\begin{array}{c}3 \\
(3)\end{array}$ & $\begin{array}{c}2 \\
(0)\end{array}$ & $\begin{array}{c}79 \% \\
(86 \%)\end{array}$ & + & N.S. & N.S. \\
\hline & & CTX & $\begin{array}{c}30 \\
(26)\end{array}$ & $\begin{array}{c}0 \\
(0)\end{array}$ & $\begin{array}{l}17 \\
(17)\end{array}$ & $\begin{array}{c}3 \\
(3)\end{array}$ & $\begin{array}{l}10 \\
(6)\end{array}$ & $\begin{array}{l}57 \% \\
(65 \%)\end{array}$ & $(+)$ & (N.S.) & (N.S.) \\
\hline \multirow{4}{*}{ Pneumonia } & \multirow{2}{*}{ No. } & CTRX & $\begin{array}{c}54 \\
(54)\end{array}$ & $\begin{array}{c}2 \\
(2)\end{array}$ & $\begin{array}{c}40 \\
(40)\end{array}$ & $\begin{array}{c}6 \\
(6)\end{array}$ & $\begin{array}{c}6 \\
(6)\end{array}$ & $\begin{array}{c}78 \% \\
(78 \%)\end{array}$ & N.S. & N.S & N.S. \\
\hline & & CTX & $\begin{array}{c}56 \\
(55)\end{array}$ & $\stackrel{1}{(1)}$ & $\begin{array}{c}45 \\
(44)\end{array}$ & $\begin{array}{l}4 \\
(4)\end{array}$ & $\begin{array}{c}6 \\
(6)\end{array}$ & $\begin{array}{l}82 \% \\
(82 \%)\end{array}$ & (N.S.) & (N.S.) & (N.S.) \\
\hline & \multirow{2}{*}{ Yes. } & CTRX & (11) & $\begin{array}{c}0 \\
(0)\end{array}$ & $\begin{array}{c}9 \\
(9)\end{array}$ & $\begin{array}{c}2 \\
(2)\end{array}$ & $\begin{array}{c}0 \\
(0)\end{array}$ & $\begin{array}{l}82 \% \\
(82 \%)\end{array}$ & N.S. & N.S & N.S. \\
\hline & & CTX & $\begin{array}{c}21 \\
(21)\end{array}$ & $\begin{array}{c}0 \\
(0)\end{array}$ & $\begin{array}{l}14 \\
(14)\end{array}$ & $\begin{array}{c}3 \\
(3)\end{array}$ & $\begin{array}{l}4 \\
(4)\end{array}$ & $\begin{array}{c}67 \% \\
(67 \%)\end{array}$ & (N.S.) & (N.S.) & (N.S.) \\
\hline \multirow{4}{*}{$\begin{array}{c}\text { Chronic } \\
\text { RTI }\end{array}$} & \multirow{2}{*}{ No. } & CTRX & $\begin{array}{l}44 \\
(41)\end{array}$ & $\begin{array}{l}2 \\
(2)\end{array}$ & $\begin{array}{c}35 \\
(32)\end{array}$ & $\begin{array}{c}4 \\
(4)\end{array}$ & $\begin{array}{l}3 \\
(3)\end{array}$ & $\begin{array}{l}84 \% \\
(83 \%)\end{array}$ & N.S. & N.S. & N.S. \\
\hline & & CTX & $\begin{array}{c}39 \\
(37)\end{array}$ & $\stackrel{2}{(2)}$ & $\begin{array}{c}28 \\
(26)\end{array}$ & $\stackrel{4}{(4)}$ & $\begin{array}{c}5 \\
(5)\end{array}$ & $\begin{array}{c}77 \% \\
(76 \%)\end{array}$ & (N.S.) & (N.S.) & (N.S.) \\
\hline & \multirow{2}{*}{ Yes. } & CTRX & (13) & $\begin{array}{c}0 \\
(0)\end{array}$ & $\begin{array}{l}10 \\
(10)\end{array}$ & $\begin{array}{l}1 \\
(1)\end{array}$ & $\begin{array}{c}2 \\
(0)\end{array}$ & $\begin{array}{c}77 \% \\
(91 \%)\end{array}$ & $*$ & N.S & + \\
\hline & & CTX & $\begin{array}{c}9 \\
(5)\end{array}$ & $\begin{array}{c}0 \\
(0)\end{array}$ & $\begin{array}{c}3 \\
(3)\end{array}$ & $\begin{array}{c}0 \\
(0)\end{array}$ & $\begin{array}{l}6 \\
(2)\end{array}$ & $\begin{array}{l}33 \% \\
(60 \%)\end{array}$ & (N.S.) & (N.S.) & (N.S.) \\
\hline
\end{tabular}

両薬剂群間の臨床症状, 胸部レ線所見の改善度 を投与開始 $3 ， 5 ， 7 ， 14$ 日後に比較した。

全例を対象とした場合, 5 日後の体温, チアノー ゼ，7日後のチアノーゼ, 脱水症状, 14日後のチ アノーゼ, 白血球数で有意差がみられ, CTRX 群 ですぐれた成績が得られた (Fig. 3). 肺炎例では $3,5,7,14$ 日後の各項目とも両群間に有意差は みられなかった (Fig. 4).

慢性気道感染例では 3 日後の血沈, 5 日後の于 アノーゼ， 7 日後のチアノーゼ, 脱水症状, 14日 後のチアノーゼ, 白血球数に括いて CTRX 群が CTX 群より有意にすぐれた成績が得られた（Fig. 5).

肺炎例に括ける胸部レ線所見の改善度では 3 , 7，14日後のいずれに括いても，両群間に有意差 はみられなかった. (Table 15).

\section{6. 主治医判定による臨床効果}

主治医により判定された臨床効果を両薬剤間で 比較した。

全例を対象とした場合, CTRX 群124例中著効 31 例, 有効68例, やや有効 14 例, 無効 8 例, 判定
不能 3 例で有効率 $82 \%$, CTX 群127例中, 著効 26 例, 有効66例, やや有効 9 例, 無効19例, 判定不 能 7 例で有効率77\%であり, 両群間に有意差はみ られなかった。

肺炎例では CTRX 群67例中, 著効22例, 有効 36 例, やや有効 4 例, 無効 3 例, 判定不能 2 例で有 効率 $89 \%, \mathrm{CTX}$ 群78例中, 著効18例, 有効 43 例, やや有効 5 例, 無効 10 例, 判定不能 2 例で有効率 80\%であった。すなわち，肺炎例を対象とした場 合 CTRX 群では CTX 群に比しすぐれた傾向が 得られた。

な技, P. aeruginosa 感染例を除外して観察する と, 肺炎例での有効率は CTRX 群で $89 \%$, CTX 群で $80 \%$ になり，先にみられた傾向差が同様にみ られた。慢性気道感染例では CTRX 群57例中, 著 効 9 例, 有効 32 例, やや有効 10 例, 無効 5 例, 判 定不能 1 例で有効率 $73 \%, \mathrm{CTX}$ 群 49 例中著効 8 例, 有効 23 例, やや有効 4 例, 無効 9 例, 判定不 能 5 例で有効率70\%であり, 両群間に有意差はみ られなかった (Table 16).

7. 副作用执よび臨床検査值異常 
Table 14 Bacteriological efficacy judged by committee

\begin{tabular}{|c|c|c|c|c|c|c|c|c|}
\hline & & $\begin{array}{l}\text { Number } \\
\text { of cases }\end{array}$ & $\begin{array}{l}\text { Eradi- } \\
\text { cated }\end{array}$ & $\begin{array}{c}\text { Decrea- } \\
\text { sed }\end{array}$ & $\begin{array}{c}\text { Un- } \\
\text { changed }\end{array}$ & Replaced & $\begin{array}{l}\text { Eradica- } \\
\text { tion rate }\end{array}$ & $\begin{array}{c}\text { Statistical } \\
\text { test }\end{array}$ \\
\hline \multirow{2}{*}{ Total } & CTRX & 44 & 35 & 2 & 4 & 3 & $80 \%$ & \multirow{2}{*}{ N.S. } \\
\hline & CTX & 53 & 42 & 5 & 4 & 2 & $79 \%$ & \\
\hline \multirow{2}{*}{ S. aureus } & CTRX & 5 & 4 & 0 & 1 & 0 & $80 \%$ & \multirow{2}{*}{ N.S. } \\
\hline & CTX & 5 & 4 & 0 & 1 & 0 & $80 \%$ & \\
\hline \multirow{2}{*}{ S. pneumoniae } & CTRX & 8 & 7 & 0 & 0 & 1 & $80 \%$ & \multirow{2}{*}{ N.S. } \\
\hline & CTX & 7 & 7 & 0 & 0 & 0 & $100 \%$ & \\
\hline \multirow{2}{*}{ S. pyogenes } & CTRX & 1 & 1 & 0 & 0 & 0 & $100 \%$ & \multirow{2}{*}{ N.S. } \\
\hline & CTX & 1 & 1 & 0 & 0 & 0 & $100 \%$ & \\
\hline \multirow{2}{*}{ GPC(Total) } & CTRX & 14 & 12 & 0 & 1 & 1 & $86 \%$ & \multirow{2}{*}{ N.S. } \\
\hline & CTX & 13 & 12 & 0 & 1 & 0 & $92 \%$ & \\
\hline \multirow{2}{*}{ E. coli } & CTRX & 2 & 1 & 0 & 0 & 1 & $50 \%$ & \multirow{2}{*}{ N.S. } \\
\hline & $\mathrm{CTX}$ & 1 & 1 & 0 & 0 & 0 & $100 \%$ & \\
\hline \multirow{2}{*}{ K. pneumoniae } & CTRX & 2 & 1 & 0 & 0 & 1 & $50 \%$ & \multirow{2}{*}{ N.S. } \\
\hline & CTX & 5 & 5 & 0 & 0 & 0 & $100 \%$ & \\
\hline \multirow{2}{*}{ Klebsiella spp. } & CTRX & 0 & & & & & & \multirow{2}{*}{$\zeta$} \\
\hline & $\mathrm{CTX}$ & 4 & 4 & 0 & 0 & 0 & $100 \%$ & \\
\hline \multirow{2}{*}{ H. influenzae } & CTRX & 9 & 9 & 0 & 0 & 0 & $100 \%$ & \multirow{2}{*}{ N.S. } \\
\hline & CTX & 14 & 12 & 1 & 0 & 1 & $86 \%$ & \\
\hline \multirow{2}{*}{ Haemophilus spp. } & CTRX & 1 & 1 & 0 & 0 & 0 & $100 \%$ & \multirow{2}{*}{ N.S. } \\
\hline & CTX & 1 & 1 & 0 & 0 & 0 & $100 \%$ & \\
\hline \multirow{2}{*}{ Citrobacter spp. } & CTRX & 0 & & & & & & \multirow{2}{*}{ I } \\
\hline & CTX & 1 & 1 & 0 & 0 & 0 & $100 \%$ & \\
\hline \multirow{2}{*}{ Enterobacter spp. } & CTRX & 0 & & & & & & \multirow{2}{*}{ Y } \\
\hline & CTX & 2 & 1 & 1 & 0 & 0 & $50 \%$ & \\
\hline \multirow{2}{*}{ Serratia spp. } & CTRX & 1 & 1 & 0 & 0 & 0 & $100 \%$ & \multirow{2}{*}{ I } \\
\hline & CTX & 0 & & & & & & \\
\hline$P$. aeruginosa & CTRX & 3 & 0 & 0 & 3 & 0 & $0 \%$ & \\
\hline & CTX & 6 & 2 & 1 & 3 & 0 & $33 \%$ & N.S. \\
\hline & CTRX & 2 & 2 & 0 & 0 & 0 & $100 \%$ & 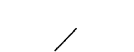 \\
\hline Uther GNR & CTX & 0 & & & & & & $\gamma^{\prime}$ \\
\hline GNR (Total) & CTRX & 20 & 15 & 0 & 3 & 2 & $75 \%$ & N.S. \\
\hline GNK (1 OLdi) & CTX & 34 & 27 & 3 & 3 & 1 & $79 \%$ & N.S. \\
\hline Single infection & CTRX & 34 & 27 & 0 & 4 & 3 & $79 \%$ & N.S. \\
\hline (Total) & $\mathrm{CTX}$ & 47 & 39 & 3 & 4 & 1 & $83 \%$ & N.s. \\
\hline Mixed & CTRX & 10 & 8 & 2 & 0 & 0 & $80 \%$ & NS. \\
\hline infection & & 6 & 3 & 2 & 0 & 1 & $50 \%$ & N.s. \\
\hline
\end{tabular}

副作用の発現した症例は CTRX 群133例中, 14 例 (10.5\%), CTX 群143例中 9 例 (6.3\%) であ り，両薬剂群間にその発現率に拈いて有意差はみ られなかった（Table 17，18）。

副作用の程度は, CTRX 群では軽度 6 例, 中等
度 8 例，CTX 群では軽度 5 例，中等度 4 例であ り，両群間に有意差はみられなかった。 副作用症状は両群で18症状みとめられ，発疹は CTRX 群で 7 例 (5.3\%), CTX 群で 1 例 (0.7\%) にみとめられ, CTRX 群で発現率が有意に高く, 
Fig. 3 Improvement of symptoms and findings (All cases)

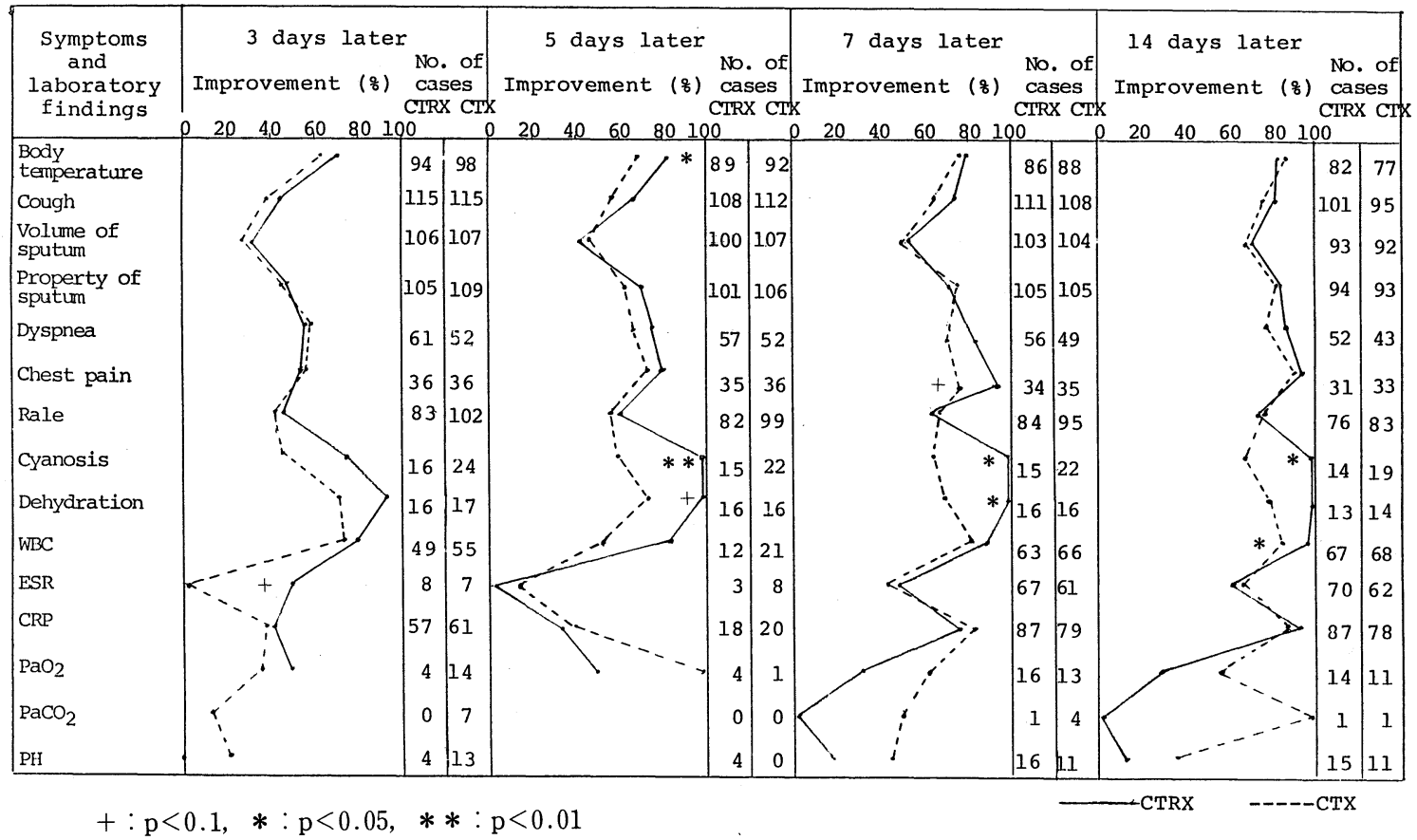

Fig. 4 Improvement of symptoms and findings (Pneumonia)

\begin{tabular}{|c|c|c|c|c|c|c|c|c|c|c|}
\hline $\begin{array}{l}\text { Symptoms } \\
\text { and } \\
\text { laboratory } \\
\text { findings }\end{array}$ & \multicolumn{2}{|c|}{ 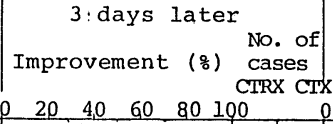 } & \multicolumn{2}{|c|}{$\begin{array}{l}5 \text { days later } \\
\text { Improvement (8) } \begin{array}{l}\text { No. of } \\
\text { cases }\end{array} \\
20 \quad 40 \quad 60 \quad 80 \quad 100\end{array}$} & \multicolumn{3}{|c|}{ 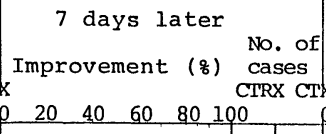 } & \multicolumn{3}{|c|}{ 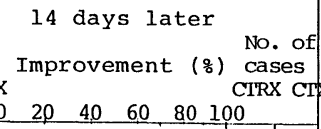 } \\
\hline $\begin{array}{l}\text { Body } \\
\text { temperature }\end{array}$ & \begin{tabular}{l|l} 
- & 52
\end{tabular} & 60 & $1 / 49$ & 57 & & 495 & 55 & $y$ & 47 & 47 \\
\hline Cough & 62 & 70 & 59 & 70 & & 60 & 68 & i) & 56 & 60 \\
\hline $\begin{array}{l}\text { Volume of } \\
\text { sputum }\end{array}$ & 53 & 64 & 50 & 64 & & 53 & 64 & & 47 & 57 \\
\hline $\begin{array}{l}\text { Property of } \\
\text { sputum }\end{array}$ & 53 & 62 & 51 & 60 & & 55 & 63 & & 48 & 56 \\
\hline Dyspnea & 25 & 24 & 22 & 24 & & 22 & 23 & & 20 & 20 \\
\hline Chest pain & 22 & 28 & 22 & 29 & & 21 & 28 & & 19 & 27 \\
\hline Rale & 45 & 58 & 45 & 56 & & $45: 5$ & 55 & & 40 & 48 \\
\hline Cyanosis & 5 & 10 & 5 & 9 & & 5 & 9 & & 5 & 8 \\
\hline Dehydration & 7 & 11 & 7 & 11 & & 71 & 10 & & 6 & 9 \\
\hline WBC & 29 & 41 & 9 & 13 & & 33 & 47 & & 39 & 42 \\
\hline ESR & 5 & 3 & 2 & 6 & & 38 & 43 & & 41 & 39 \\
\hline CRP & 33 & 40 & 11 & 13 & & 475 & 58 & & 48 & 52 \\
\hline $\mathrm{PaO}_{2}$ & 2 & 7 & 2 & 1 & & 7 & 8 & $\therefore=$ & 5 & 6 \\
\hline $\mathrm{PaCO}_{2}$ & 0 & 2 & 0 & 0 & & 0 & 2 & & 0 & 0 \\
\hline $\mathrm{PH}$ & 2 & 7 & 2 & 0 & i & 6 & 7 & & 4 & 6 \\
\hline
\end{tabular}


Fig. 5 Improvement of symptoms and findings (Chronic RTI)

\begin{tabular}{|c|c|c|c|c|c|c|c|c|c|c|c|c|}
\hline \multirow{2}{*}{$\begin{array}{c}\text { Symptoms } \\
\text { and } \\
\text { laboratory } \\
\text { findings }\end{array}$} & \multirow{2}{*}{\multicolumn{3}{|c|}{ 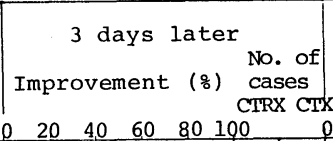 }} & \multirow{2}{*}{\multicolumn{3}{|c|}{$\begin{array}{l}5 \text { days later } \\
\text { Improvement }(\%) \begin{array}{l}\text { No. of } \\
\text { cases }\end{array} \\
20 \quad 40 \quad 60 \quad 80 \quad 100\end{array}$}} & \multirow{2}{*}{$\begin{array}{l}7 \text { days later } \\
\text { Improvement }(\%) \\
0 \quad 20 \quad 40 \quad 60 \quad 80 \quad 10\end{array}$} & \multicolumn{2}{|c|}{$\begin{array}{l}\text { No. of } \\
\text { cases } \\
\text { CTRX CTX }\end{array}$} & \multirow{2}{*}{\multicolumn{3}{|c|}{ 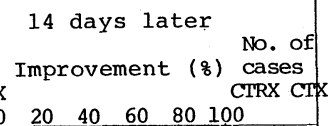 }} \\
\hline & & & & & & & & & & & & \\
\hline $\begin{array}{l}\text { Body } \\
\text { temperature }\end{array}$ & & 42 & 38 & & 40 & 35 & & 37 & 33 & & 35 & 30 \\
\hline Cough & & 53 & 45 & & 49 & 42 & & 51 & 40 & & & \\
\hline $\begin{array}{l}\text { Volume of } \\
\text { sputum }\end{array}$ & & 53 & 43 & & 50 & 43 & & 50 & 40 & & 46 & 35 \\
\hline $\begin{array}{l}\text { Property of } \\
\text { sputum }\end{array}$ & & 52 & 47 & & 50 & 46 & & 50 & 42 & & 46 & 37 \\
\hline Dyspnea & & 36 & 28 & & 35 & 28 & & 34 & 26 & & 32 & 23 \\
\hline Chest pain & & 14 & 8 & & 13 & 7 & & 13 & 7 & & 12 & 6 \\
\hline Rale & & 38 & 44 & & 37 & 43 & & 39 & 40 & & 36 & 35 \\
\hline Cyanosis & & 11 ? & 14 & & 10 & 13 & & 10 & 13 & & 9 & 11 \\
\hline Dehydration & & 9 & 6 & & 9 & 5 & & 9 & 6 & & 7 & 5 \\
\hline WBC & & 20 & 14 & & 3 & 8 & & 30 & 19 & & 28 & 26 \\
\hline ESR & & 3 & 4 & & 1 & 2 & & 29 & 18 & & 29 & 23 \\
\hline CRP & & 242 & 21 & & 7 & 7 & & 40 & 21 & & 39 & 26 \\
\hline $\mathrm{PaO}_{2}$ & & 2 & 7 & & 2 & 0 & & 9 & 5 & & 9 & 5 \\
\hline $\mathrm{PaCO}_{2}$ & & 0 & 5 & & 0 & 0 , & & 1 & 2 & & 1 & 1 \\
\hline $\mathrm{PH}$ & : & 2 & 6 & & 2 & 0 & & 10 & 4 & & 11 & 5 \\
\hline
\end{tabular}

Table 15 Improvement in chest X-ray findings

\begin{tabular}{|c|c|c|c|c|c|c|}
\hline & Drug & $\begin{array}{l}\text { Number } \\
\text { of cases }\end{array}$ & Improved & Unchanged & Aggravated & $\begin{array}{c}\text { Statistical } \\
\text { test }\end{array}$ \\
\hline \multirow{2}{*}{$\begin{array}{l}3 \text { days } \\
\text { later }\end{array}$} & CTRX & 46 & $\begin{array}{c}30 \\
(65 \%)\end{array}$ & 6 & 10 & \multirow{2}{*}{ N.S. } \\
\hline & CTX & 52 & $\begin{array}{c}34 \\
(65 \%)\end{array}$ & 12 & 6 & \\
\hline \multirow{2}{*}{$\begin{array}{l}7 \text { days } \\
\text { later }\end{array}$} & CTRX & 60 & $\begin{array}{c}49 \\
(82 \%)\end{array}$ & 6 & 5 & \multirow{2}{*}{ N.S. } \\
\hline & CTX & 72 & $\begin{array}{c}59 \\
(82 \%)\end{array}$ & 7 & 6 & \\
\hline \multirow{2}{*}{$\begin{array}{l}14 \text { days } \\
\text { later }\end{array}$} & CTRX & 48 & $\begin{array}{c}45 \\
(94 \%)\end{array}$ & 2 & 1 & \multirow{2}{*}{ N.S. } \\
\hline & CTX & 60 & $\begin{array}{c}54 \\
(90 \%)\end{array}$ & 4 & 2 & \\
\hline
\end{tabular}

呕気はCTRX 群 5 例 $(3.8 \%)$, CTX 群 1 例 (0.7\%)にみとめられ，CTRX 群に和ける発現率 は高い傾向がみられた。その他の副作用症状の発 現率は両群間に有意差はみられなかった。

また，臨床検査值異常を呈した症例は CTRX 群130例 中 37 例 (28.5\%), CTX 群137例 中36例 (26.3\%)であり，両群間に有意差はみられなかっ た (Table 19, 20).

臨床検査值異常の程度は CTRX 群では軽度34 例, 中等度 3 例, CTX 群では軽度33例, 中等度 3
例であり，両群間に有意差はみられなかった。 臨床検査値異常は両群で11項目みとめられ，白 血球数减少が CTRX 群で 8 例 $(6.2 \%)$, CTX 群 で 3 例 $(2.2 \%)$ によめられ，CTRX 群の発現率 に高い傾向がみられた，その他の臨床検査值異常 の発現率には両群間に有意差はみられなかった。

8. 小委員会判定による有用性

小委員会に和いて判定された有用性を両薬剤間 で比較した。

CTRX 群133例中, 極めて有用 3 例, 有用94例, 
Table 16 Clinical efficacy judged by doctor

\begin{tabular}{|c|c|c|c|c|c|c|c|c|c|}
\hline & Drug & $\begin{array}{l}\text { Number } \\
\text { of cases }\end{array}$ & $\begin{array}{l}\text { Exce- } \\
\text { llent }\end{array}$ & Good & Fair & Poor & $\begin{array}{l}\text { Inevalu- } \\
\text { able }\end{array}$ & $\begin{array}{l}\text { Efficacy } \\
\text { rate }\end{array}$ & $\begin{array}{l}\text { Statistical } \\
\text { test }\end{array}$ \\
\hline \multirow{2}{*}{ All cases } & CTRX & $\begin{array}{c}124 \\
(119)\end{array}$ & $\begin{array}{c}31 \\
(30)\end{array}$ & $\begin{array}{c}68 \\
(67)\end{array}$ & $\begin{array}{c}14 \\
(13)\end{array}$ & $\begin{array}{c}8 \\
(6)\end{array}$ & $\begin{array}{c}3 \\
(3)\end{array}$ & $\begin{array}{l}82 \% \\
(84 \%)\end{array}$ & N.S. \\
\hline & CTX & $\begin{array}{l}127 \\
(120)\end{array}$ & $\begin{array}{c}26 \\
(26)\end{array}$ & $\begin{array}{c}66 \\
(63)\end{array}$ & $\begin{array}{c}9 \\
(9)\end{array}$ & $\begin{array}{l}19 \\
(16)\end{array}$ & $\begin{array}{c}7 \\
(6)\end{array}$ & $\begin{array}{c}77 \% \\
(78 \%)\end{array}$ & (N.S.) \\
\hline \multirow{2}{*}{ Pneumonia } & CTRX & $\begin{array}{c}67 \\
(67)\end{array}$ & $\begin{array}{c}22 \\
(22)\end{array}$ & $\begin{array}{c}36 \\
(36)\end{array}$ & $\begin{array}{c}4 \\
(4)\end{array}$ & $\begin{array}{c}3 \\
(3)\end{array}$ & $\stackrel{2}{(2)}$ & $\begin{array}{c}89 \% \\
(89 \%)\end{array}$ & $\begin{array}{c}\text { CTRX > CTX } \\
+[\text { Wilcoxon] }\end{array}$ \\
\hline & CTX & $\begin{array}{c}78 \\
(77)\end{array}$ & $\begin{array}{c}18 \\
(18)\end{array}$ & $\begin{array}{c}43 \\
(42)\end{array}$ & $\begin{array}{c}5 \\
(5)\end{array}$ & $\begin{array}{l}10 \\
(10)\end{array}$ & $\stackrel{2}{(2)}$ & $\begin{array}{l}80 \% \\
(80 \%)\end{array}$ & $\left(\begin{array}{l}\text { CTRX > CTX } \\
+[\text { Wilcoxon }]\end{array}\right)$ \\
\hline \multirow{2}{*}{ Chronic RTI } & CTRX & $\begin{array}{c}57 \\
(52)\end{array}$ & $\begin{array}{c}9 \\
(8)\end{array}$ & $\begin{array}{c}32 \\
(31)\end{array}$ & $\begin{array}{l}10 \\
(9)\end{array}$ & $\begin{array}{c}5 \\
(3)\end{array}$ & $\begin{array}{l}1 \\
(1)\end{array}$ & $\begin{array}{c}73 \% \\
(76 \%)\end{array}$ & N.S. \\
\hline & CTX & $\begin{array}{c}49 \\
(43)\end{array}$ & $\begin{array}{c}8 \\
(8)\end{array}$ & $\begin{array}{c}23 \\
(21)\end{array}$ & $\begin{array}{c}4 \\
(4)\end{array}$ & $\begin{array}{c}9 \\
(6)\end{array}$ & $\begin{array}{c}5 \\
(4)\end{array}$ & $\begin{array}{c}70 \% \\
(74 \%)\end{array}$ & (N.S.) \\
\hline
\end{tabular}

Table 17 Degree of side effects judged by committee

\begin{tabular}{lrr}
\hline \multicolumn{1}{c}{ Drug } & CTRX & CTX \\
\hline Number of cases & 133 & 143 \\
\hline None & 119 & 134 \\
Mild & 6 & 5 \\
Moderate & 8 & 4 \\
Severe & 0 & 0 \\
\hline Statistical test & \multicolumn{3}{c}{ N.S. } \\
\hline
\end{tabular}

Table 18 Side effects

\begin{tabular}{lcccccc}
\hline & $\begin{array}{c}\text { Number } \\
\text { of cases }\end{array}$ & CTRX & CTX & $\begin{array}{c}\text { Statistical } \\
\text { test }\end{array}$ \\
\hline $\begin{array}{c}\text { Number } \\
\text { of all cases }\end{array}$ & 276 & 133 & & 143 & & \\
\hline $\begin{array}{c}\text { Cases with } \\
\text { side effects }\end{array}$ & 23 & 14 & $10.5 \%$ & 9 & $6.3 \%$ & N.S. \\
\hline Eruption & 8 & 7 & $5.3 \%$ & 1 & $0.7 \%$ & $*$ (Fisher) \\
Redness & 1 & 1 & $0.8 \%$ & 0 & & N.S. \\
Rash & 1 & 0 & & 1 & $0.7 \%$ & N.S. \\
Stomatitis & 1 & 0 & & 1 & $0.7 \%$ & N.S. \\
Fever & 7 & 5 & $3.8 \%$ & 2 & $1.4 \%$ & N.S. \\
Feeling hot & 1 & 1 & $0.8 \%$ & 0 & & N.S. \\
Hot flushes & 1 & 1 & $0.8 \%$ & 0 & & N.S. \\
Diarrhea & 3 & 1 & $0.8 \%$ & 2 & $1.4 \%$ & N.S. \\
Soft stool & 1 & 1 & $0.8 \%$ & 0 & & N.S. \\
Abdominal pain & 1 & 1 & $0.8 \%$ & 0 & & N.S. \\
Anorexia & 1 & 1 & $0.8 \%$ & 0 & & N.S. \\
Nausea & 6 & 5 & $3.8 \%$ & 1 & $0.7 \%$ & + (Fisher $)$ \\
Vomiting & 3 & 2 & $1.5 \%$ & 1 & $0.7 \%$ & N.S. \\
Headache & 1 & 1 & $0.8 \%$ & 0 & & N.S. \\
Wooziness & 1 & 0 & & 1 & $0.7 \%$ & N.S. \\
Chest distress & 1 & 0 & & 1 & $0.7 \%$ & N.S. \\
Dyspnea & 1 & 0 & & 1 & $0.7 \%$ & N.S. \\
Palpitation & 1 & 0 & & 1 & $0.7 \%$ & N.S. \\
\hline & & & $+: \mathrm{p}<0.1, *$ & $*$ p $<0.05$ \\
& & & & &
\end{tabular}

Table 19 Degree of abnormal laboratory findings judged by committee

\begin{tabular}{lcr}
\hline \multicolumn{1}{c}{ Drug } & CTRX & CTX \\
\hline Number of cases & 130 & 137 \\
\hline None & 93 & 101 \\
Mild & 34 & 33 \\
Moderate & 3 & 3 \\
Severe & 0 & 0 \\
\hline Statistical test & \multicolumn{3}{c}{ N.S. } \\
\hline
\end{tabular}

やや有用13例，有用性なし20例，判定不能 3 例， CTX 群143例中，極めて有用 2 例，有用90例，や や有用14例, 有用性なし28例, 判定不能 9 例であ り，両群間に有意差はみられなかった。

\section{考 案}

CTRX は先にも述べたごとく, その抗菌スペク トラムは，いわゆる第三世代のセフェム系とほぼ 同範囲であるが, 血中半減期が7.4時間と, きわ だって長いことがその特徵である。また家鬼を用 いた実験的観察に打いても，肺内リンパ流量への 移行はすぐれており，かつ本剤のリンパ液中での 滞留も他のセフェム剤に比し, きわめて長期であ る4).さらに喀痰中への移行も良好な成績が示さ れている。

全国規模の研究会組織で実施された臨床試験に おける肺炎203例, 慢性気管支炎84例での有効率は それぞれ79\%,80\%であり ${ }^{1)}$, 下気道領域以下の呼 吸器感染症 378 例に対する有効率は76\%であり,そ の症例背景を考慮した場合, これら領域の感染症 
Table 20 Abnormal laboratory findings

\begin{tabular}{|c|c|c|c|c|c|c|c|}
\hline & & CTRX & & & CTX & & \\
\hline & $\begin{array}{l}\text { Number } \\
\text { of all } \\
\text { cases }\end{array}$ & $\begin{array}{l}\text { Cases with } \\
\text { laboratory } \\
\text { abnormalities }\end{array}$ & Incidence & $\begin{array}{l}\text { Number } \\
\text { of all } \\
\text { cases }\end{array}$ & $\begin{array}{c}\text { Cases with } \\
\text { laboratory } \\
\text { abnormalities }\end{array}$ & Incidence & $\begin{array}{l}\text { Statistical } \\
\text { test }\end{array}$ \\
\hline $\mathrm{WBC} \downarrow$ & 130 & 8 & $6.2 \%$ & 136 & 3 & $2.2 \%$ & + (Fisher) \\
\hline $\mathrm{Hb} \downarrow$ & 128 & 1 & $0.8 \%$ & 135 & 0 & & N.S. \\
\hline Eosinophilia & 128 & 14 & $10.9 \%$ & 130 & 11 & $8.5 \%$ & N.S. \\
\hline GOT $\uparrow$ & 129 & 15 & $11.6 \%$ & 136 & 12 & $8.8 \%$ & N.S. \\
\hline GPT $\uparrow$ & 127 & 15 & $11.8 \%$ & 136 & 15 & $11.0 \%$ & N.S. \\
\hline $\mathrm{Al}-\mathrm{P} \uparrow$ & 128 & 5 & $3.9 \%$ & 133 & 4 & $3.0 \%$ & N.S. \\
\hline $\mathrm{BUN} \uparrow$ & 128 & 3 & $2.3 \%$ & 135 & 4 & $3.0 \%$ & N.S. \\
\hline Creatinine $\uparrow$ & 126 & 0 & & 134 & 2 & $1.5 \%$ & N.S. \\
\hline Urinary protein $(+)$ & 117 & 1 & $0.9 \%$ & 126 & 2 & $1.6 \%$ & N.S. \\
\hline $\begin{array}{l}\text { Urinary sediment } \\
\text { erythrocyte }(+)\end{array}$ & 110 & 1 & $0.9 \%$ & 119 & 0 & & N.S. \\
\hline $\begin{array}{l}\text { Urinary sediment } \\
\text { cylinder }(+)\end{array}$ & 88 & 1 & $1.1 \%$ & 102 & 0 & & N.S. \\
\hline Total & 130 & 37 & $28.5 \%$ & 137 & 36 & $26.3 \%$ & N.S. \\
\hline
\end{tabular}

Table 21 Utility evaluated by committee

\begin{tabular}{|c|c|c|c|c|c|c|c|}
\hline & $\begin{array}{l}\text { Number } \\
\text { of cases }\end{array}$ & $\begin{array}{l}\text { Very } \\
\text { useful }\end{array}$ & Useful & $\begin{array}{l}\text { Slightly } \\
\text { useful }\end{array}$ & Useless & $\begin{array}{l}\text { Inevalu- } \\
\text { able }\end{array}$ & $\begin{array}{c}\text { Statistical } \\
\text { test }\end{array}$ \\
\hline CTRX & 133 & 3 & 94 & 13 & 20 & 3 & \multirow{2}{*}{ N.S. } \\
\hline С'TX & 143 & 2 & 6) 90 & 14 & 28 & 9 & \\
\hline
\end{tabular}

に対してこの段階でほぼ期待できる成績が得られ たものと解せよう。

一方, CTRX の投与量について, やはり全国集 計の成績をみると ${ }^{1)}$, 全症例 1,067 例中, 1 日 $1 \mathrm{~g}$ が 497例，1 日 $2 \mathrm{~g}$ が482例と最も多く，かつその臨床 効果も前者で $77 \%$ ，後者で $81 \%$ であった。ささに 1 日投与回数といら観点から先の全国集計を観察 すると 1,067 例中 2 回投与は 596 例 $56 \%$ と示された が，本剤の血中半減期が長いこと考慮してか 1 日 1 回投与が423例 $40 \%$ にられて拈り，さらに 2 日 に 1 回投与といら例も10例にみられていた。これ ら投与回数別有効率もそれぞれ79\%，79\%，60\% であり，1回投与と 2 回投与の間ではほとんど差 がみられなかった。このことは主治医が投与回数 を選択した時点で，症例の重症度を勘案したこと にもよろらが，本剤に限って 1 回投与例が多かっ たことはやはり本剤の特徴が反映されたものとみ ることができょう。
本比較試験前にも，本試験における CTRXの 1 日投与回数が論議されたが，比較試験遂行の上 で W一ダミ一方式がきわめてむずかしいこと，プ ラセボ投与が症例に対して注射といら多少とも苦 痛を伴う行為を強制すること，さらに本来第三世 代抗菌剂が対象となるような重症あるいは難治症 例では通常 1 日 2 回投与がなされていたという現 実，扣よび試験にとらわれたための患者の不利益 性などを考慮し，1 日 2 回投与法が企図されたわ けである。

このような経緯から本試験は実施されたわけで あるが，288症例が集積され，そのうち251例が効 果判定可能例として選択された。このらち, 当初 対象菌種外之約束された $P$. aeruginosa が起炎菌 として考兄られた 12 例（うち混合感染 3 例）がみ られた。本剤の取り扱いについて小委員会でも論 議されたが，本剤が一般に用いられた場合には， かかる症例のこの程度の混入は止むを得ないであ 
ろらとの考えから, 併せて集計し, 臨床効果を観 察する場合には層別解析を行らといらことで意見 の一致をみ，また各主治医との間でも諒解が得ら れた. 開封の結果, P. aeruginosa が当初関与した 例は 12 例中 CTRX 群に 5 例, CTX 群に 7 例がみ られて拉り, 臨床効果についてはこれらの例を除 いた効果も併記した。

さて, 両群の背景因子を観察すると, 年齢, 性, 体重, 重症度, 基礎疾患の有無とその内容, 前投 与抗菌剂等すべてを比較した限りでは諸項目に差 はみとめられず，従って両集団を均質の背景を有 するものとして以下比較検討に供された。

小委員会判定による臨床効果については，解析 対象症例全例で CTRX 群の有効率は $81 \%$, CTX 群74\%であり有意差はみられなかったが，いわゆ る慢性気道疾患群に層別した場合, CTRX 群 $82 \%$, CTX 群 $67 \%$ と CTRX 群に高い有効率が示され, 傾 向差が観察された。しかしながらここでP. aeru: ginosa感染例を除外してみた場合，その有効率は CTRX 群 $85 \%$, CTX 群72\%となり, CTRX 群にお いて数值の上で高い有効率が得られたが, 統計学 的には傾向差, 有意差ともみられなかった。 また 主治医判定に扮ける肺炎群では CTRX 群に高い 有効率が示され傾向差がみられ，P. aeruginosa感 染例を除外してみた場合も同様に傾向差がみられ た。さらにP. aeruginosa感染例を除外して集計 した場合をも含めて臨床効果の点で統計学的差が みられた項目は重症度別にみた場合の中等症の群 であり，重症例を含めたいわゆる「中等症以上」で 層別分析を行らと, CTRX 群の有効率 $80 \%$, CTX 群の有効率 $60 \%$ また, P. aeruginosa 感染例を除 いた例での CTRX 群では有効率 $81 \%$, CTX 群で は有効率 $62 \%$ となり, CTRX 群は CTX 群に比し, 有意にすぐれた成績が得られていた。

このことは，一般に感染症状が重症になる程, 今回の投与方法の範囲内に特いて CTRXが CTXよりもその効果がさらに期待できることを 示唆しているものとも考兄られ，招そらく本剤の 血中濃度持続性が，その一因として考えられるこ とも出来よう.

細菌学的効果について, 除菌率は CTRX 群 44
例中 35 例 $80 \%$ ，CTX 群53例中，42例79\%であり， 両群間に有意差はみられなかった。らち, 呼吸器 感染症においてしばしばみられ，かつ本試験に括 いても比較的株数の多かったS. pneumoniae, $H$. influenzae 等に拉いても両薬剤ともにすぐれた除 菌効果が示された。 また，グラム陽性菌，陰性菌 別に集計しても，その除菌率は陽性菌で CTRX86 \%, CTX92\%, 陰性菌で CTRX75\%, CTX79\%と， CTX 群で若干高い値が示されたが有意差はみら れなかった。一方, P. aeruginosa に関しては混合 感染例を含めて CTRX 群 5 例中消失 0 例であっ たが, CTX 群 7 例中消失 2 例であり, 例数は少な かったが，後者において高い率がみられたことは in vitro に㧧いて存在する CTX の抗緑膿菌作用 が反映したものと考えられた。

交代菌あるいは投与後出現菌はCTRX 群で 3 例, CTX 群 2 例がみられ, 菌種は前者で $P$. aer uginosa 2 株, S. aureus, A. anitratus 各 1 株, 後者で, P. aeruginosa 2 株であり, 両群間で特筆 すべき現象はみられなかった。

臨床症状を主体とした副作用の発現率は, CTRX 群133例中14例10.5\%, CTX 群143例中 9 例 $6.3 \%$ であり, 数值の点で CTRX 群が高值で あったが両群間に有意差はみられなかった。

臨床検査値異常についても両群間に有意差はみ られなかった。

先にも述べたごとく両薬剤の血中濃度半減期は CTRX で約 7 時間, CTX で0.9時間と, 本試験で は極度に長いものと短かいものの比較であるが， この場合臨床効果はともかくとして血中濃度持続 性の薬剂の副作用はいかなる形で出現するか，今 後も十分慎重に留意すべきであろう。

これら副作用と先の臨床効果を勘案した結果の 有用性については「有用以上」と判定した例での 「有用率」は CTRX 群75\%, CTX 群69\%であり, 両群間に打いて有意差は示されず，ともに満足す べき值が得られた。

以上，下気道領域の呼吸器感染症，すなわちい わゆる慢性気道感染と肺炎を対象とした場合，と くに中等症招よび中等症以上の症例で CTRX が CTX に若干すぐれた成績を得たことは，両薬剤 
の抗菌性もさることながら，血中濃度半減期の長 さによることも考学られ, CTRX はこの領域の呼 吸器感染症に対して臨床上その効果がさらに一歩 期待できる薬剤と考えられた。

本研究にあたり，コントローラーを扮引き受けいただい た東京大学医学部保健管理学教室田中恒男教授ならびに細 菌学的検索を护引き受けいただいた東京薬科大学第二微生 物学教室河野恵教授に深謝いたします。

なお，本試験は故中川圭一東京共済病院長が研究代表者 として実施されたものであったが、コントローラーの解析 集計に基づき，各参加施設の承諾の上で小林宏行により執 筆がなされたものである.

\section{文献}

1）第29回日本化学療法学会東日本支部総会新薬シン ポジウム. Ceftriaxone (Ro 13-9904), 1982.

2) Stoeckel, K. : Pharmacokinetics of Rocephin ${ }^{\circledR}$, a highly active new cephalosporin with an exceptionally long biological half-life. Chemotherapy, 27(Suppl. 1) : 42-46, 1981.

3) Patel, I.H., et al.: Pharmacokinetics of Ceftriaxone in humans. Antimicrob. Agents Chemother., 20(5) : 634-641, 1981.

4) Takamura, K.: Experimental study on lymph transfer of some new antibiotics. Program of 13th. International Congress of Chemotherapy, p. $355,1983$.

A Well-Contorolled Comparative Study on Ceftriaxone with Cefotaxime in Respiratory Tract Infections

Hiroyuki KOBAYASHI, Kenji TAKAMURA, Hiroshi OSHITANI \& Tomoko NIHEI

Department of Internal Medicine, Kyorin University, School of Medicine

Akira SAITO, Masumi TOMIZAWA, Ichiro NAKAYAMA, Kiyofumi ISHIKAWA, Morikuni ABE, Yoshihiko KURODA, Hiroyuki KUMANO, Yoshio KURIHARA, Tuyoshi KIKUIRI \& Shuzaburo FUKUYAMA

The Second Department of Internal Medicine, School of Medicine, Hokkaido University

Fumio NAGAHAMA, Shinya YASUDA, Akira SUZUKI, Yomei HIRAGA, Mitsuharu OGI,

Akihiko KUZE, Hiroshi KON, Katsuo SUZUKI, Sensuke KURODA \& Jutaro SHIMOMURA

Respiratory Department, National Sapporo Hospital

Kazuo TAKEBE, Seiichi MURAKAMI, Morio SAGARA, Masahiro TSUTSUI, Shunichi MAEDA, Seiichi OHHIRA, Mitsuo MASUDA, Yuzo MORI, Kazuo SASAKI, Mitsuo SUZUKI, Makoto NAKAZONO, Kiyohito TAKAHASHI, Hisashi NAKAHATA \& Shirou KOSAKA

The Third Department of Internal Medicine, Hirosaki University, School of Medicine Masao TAMURA, Takashi ITO, Takehisa MURAKAMI \& Kohtaro ITAKURA The Third Department of Internal Medicine, Iwate Medical University, School of Medicine Tamotsu TAKISHIMA \& Shiroh IDA

The First Department of Internal Medicine, Tohoku University, School of Medicine Kiyoshi KONNO, Kikuo ONUMA, Kotaro OIZUMI, Masako SASAKI, Akira WATANABE, Seiichi AONUMA \& Reiko SASAKI

Department of Medicine, The Research Institute for Chest Diseases and Cancer, Tohoku University Izumi HAYASHI

Division of Respiratory Disease, Iwaki Kyoritsu General Hospital Masataka KATSU

Department of Internal Medicine, Kasumigaura National Hospital Keimei MASHIMO, Yoshiji YAMANE \& Sumio YAMAOKA

Department of Internal Medicine, Tokyo Koseinenkin Hospital

Atsushi SAITO, Jingoro SHIMADA, Koya SHIBA, Takehisa YAMAJI, Toshio HOJO, Masanobu KAJI \& Tadashi MIYAHARA

The Second Department of Internal Medicine, The Jikei University, School of Medicine 
Hideo IKEMOTO \& Kazuyoshi WATANABE

Department of Internal Medicine, Juntendo University, School of Medicine Keiichi NAKAGAWA, Kentaro WATANABE, Masaru KOYAMA \& Fukuo IJIMA

Department of Internal Medicine, Tokyo Kyosai Hospital

Kaoru SHIMADA, Takashi INAMATSU \& Kyoko URAYAMA

Department of Internal Medicine, Tokyo Metoroporitan Geriatric Hospital

Hiroichi TANIMOTO, Kunihiko YOSHIMURA, Tatsuo NAKATANI, Naohiko CHONABAYASHI, Yoshitaka NAKAMORI \& Koichiro NAKATA

Chest Clinical, Toranomon Hospital

Junzaburo KABE, Hiroyoshi ISHIBASHI \& Yasuyuki SANO

Department of Respiratory Disease, Tokyo National Medical Canter

Ippei FUJIMORI, Yoshio KOBAYASHI \& Akio ONAKA

Department of Internal Medicine, Kawasaki Municipal Hospital

Kazufuto FUKAYA

Department of Internal Medicine, Yokohama Teishin Hospital

Shigeki ODAGIRI, Kouu MUROHASHI, Hirotada IKEDA, Kaneo SUZUKI \& Tamotsu KANEKO

Department of Respiratory Diseases, Kanagawa Prefectural Nagahama Hospital

Toshihiko TAKEUCHI, Toshiyuki YAMAMOTO \& Masahito KATO

The First Department of Internal Medicine, Medical School, Nagoya City University

Kouichi WADA \& Masaaki ARAKAWA

Second Department of Internal Medicine, Niigata University, School of Medicine

Osamu SEKINE, Yoshimura USUDA \& Nobuki AOKI

Department of Internal Medicine, Shinrakuen Hospital

Fusanosuke YAMASAKU \& Yasutoshi SUZUKI

Department of Internal Medicine, Suibarago Hospital

Kaoru OYAMA

Department of Internal Medicine, Toyama Prefectural Central Hospital

Nobuo MAEKAWA, Michiyasu NAKANISHI, Yujiro SUZUKI \& Keijyu LEE

First Department of Internal Medicine, Chest Disease Research Institute, Kyoto University

Hiroshi OKUBO \& Yoshihiro UEDA

Department of Internal Medicine, Rakusei New Town Hospital, Kansai Medical University

Yuruko OKAMOTO, Keigo MAEHARA, Seibun YONEZU \& Yube IIDA

First Department of Internal Medicine, Kansai Medical University

Fumio MIKI, Yoshiyasu IKUNO, Eiji INOUE, Minoru YOSHIYAMA, Tetsuto MURATA,

Shinichi TANIZAWA \& Kazuo SAKAMOTO

Department of Internal Medicine, Tane General Hospital

Rinzo SOEJIMA \& Yoshito NIKI

Division of Respirotory Diseases, Department of Medicine, Kawasaki Medical School

Osamu KURIMURA, Hideo SASAKI \& Hirofumi FUKUHARA

Department of Internal Medicine, Kure National Hospital

Eiro TSUBURA, Masakazu TAMURA \& Masaru NAKAGAWA

Third Department of Internal Medicine, School of Medicine, The University of Tokushima

Yoshiro SAWAE, Kaoru OKADA \& Yukio KUMAGAI

The First Department of Internal Medicine, Faculty of Medicine, Kyushu University

Hitoshi NAGANO \& Chiharu KUBO

Clinical Department, The Minami Fukuoka National Chest Hospital

Takashi ITOGA, Masaru NASU, Jun GOTO, Yoichiro GOTO \& Takayoshi TASHIRO

Second Department of Internal Medicine, Medical College of Oita 


\section{Kohei HARA, Atsushi SAITO, Keizo YAMAGUCHI, Yoji SUZUYAMA, Yoshiteru SHIGENO, Toshiyuki OYE, Hiromaru IWASAKI \& Toshiaki HAYASHI \\ The Second Department of Internal Medicine, Nagasaki University, School of Medicine Keizo MATSUMOTO, Yukio NOGUCHI \& Mikio TAGUCHI \\ The Department of Internal Medicine, Institute for Tropical Medicine, Nagasaki University}

For the purpose of evaluating the efficacy, safety and usefulness of ceftriaxone (CTRX), a cephem antibiotic, in respiratory tract infections, a well-controlled comparative study was carried out with cefotaxime (CTX) for a reference.

One (1) gm of either CTRX or CTX was administered by drip infusion twice a day for 7 to 14 days in principle into patients with chronic bronchitis and diffuse panbronchiolitis aggravated with infections, chronic respiratory diseases accompanied with infections in the lower respiratory tract like bronchiectasis, bronchial asthma, pulmonary emphysema, pulmonary fibrosis, obsolete pulmonary tuberculosis, lung cancer, etc. and bacterial pneumonia.

Results were as follows:

1) Clinical efficacy: The efficacy rate was $81 \%$ (100/124) with CTRX and $74 \%$ (94/127) with CTX, with no statistically significant difference between the two drugs. The efficacy rate in the moderately infected patients was $81 \%$ (54/67) with CTRX and $62 \%$ (37/60) with CTX, CTRX being significantly superior to CTX. If cases infected with P. aerugirrosa were excluded, CTRX was higher in efficacy than CTX.

2) Bacteriological effects: The bacterial eradication occurred in 35 patients out of $44(80 \%)$ with CTRX and in 42 out of $54(78 \%)$ with CTX, with no statistically significant difference. There was no significant difference in efficacy between the two, whether according to strains of isolates or types of infections (single or mixed).

3) Adverse reactions: The incidence of adverse reactions was $10.5 \%(14 / 133)$ to CTRX and $6.3 \%$ (9/143) to CTX, no statistically significant difference being noticed. The incidence of skin rash was significantly higher with CTRX. In the clinical laboratory test, abnormal signs were observed in 37 out of $130(28.5 \%)$ with CTRX and in 36 out of 137 (26.3\%) with CTX, no significant difference being detected.

4) Usefulness: CTRX was evaluated to be very useful in 3 out of 133, useful in 94 , slightly useful in 13 and useless in 20. There were 3 unevaluable cases. CTX was very useful in 2 out of 143, useful in 90, slightly useful in 14 and useless in 28. Evaluation was impossible in 9 cases. There was no significant difference in usefulness between CTRX and CTX.

5) Conclusion: From the above, CTRX was considered to be clinically very useful for the treatment of infections of the lower respiratory tract like chronic respiratory tract infections and pneumonia. 